\title{
THE FLANDRIAN HISTORY OF LAKE HÖYTIÄINEN, EASTERN FINLAND
}

\author{
Matti SaARnisto \\ Department of Geology and Palaeontology, University of Helsinki, Finland
}

\begin{abstract}
The present paper on the Flandrian history of Lake Höytiäinen, eastern Finland, is based on stratigraphical and shore morphological investigations. Lake Höytiäinen is situated on the proximal side of a great end moraine, Jaamankangas. The final retreat of the ice during the Weichselian glaciation started from Jaamankangas about 10000 years B.P. Lake Höytiäinen was isolated from the final stage of the Yoldia Sea $8500-8900$ years B.P. This age is compatible with the result of Sauramo and Auer (1928). The diatom analysis does not show any influence of salt water before the isolation.

After the isolation a transgression started on the SE-side of the isolation threshold and a regression on the NWside of it. The shore-line displacement of the lake is studied only stratigraphically because no raised beach before the clear shore of 1859 has been found. In 1859 the water of Lake Höytiäinen forced a dam of the canal being built in Jaamankangas and eroded a new outlet through it to Lake Pyhäselkä. The water level fell in a month about 9.5 metres.
\end{abstract}

\section{CONTENTS}

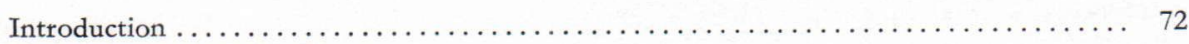

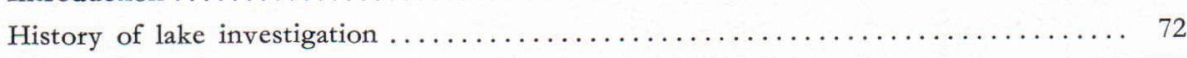

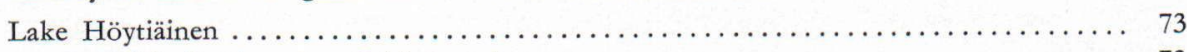

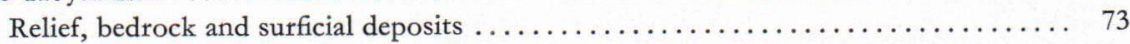

Earlier views on the Late-Weichselian and Flandrian history of Lake Höytiäinen . . . . 74

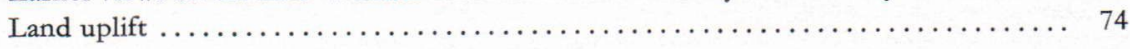

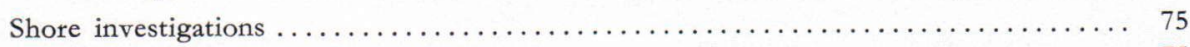

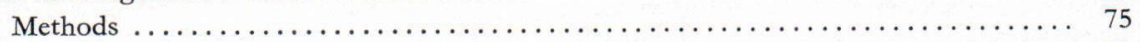

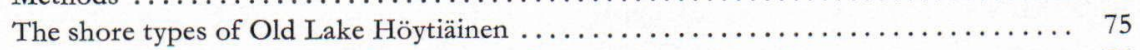

The suitability of the shores for the investigation of raised beaches $\ldots \ldots \ldots \ldots \ldots .76$

Marine raised beaches in the basin of Lake Höytiäinen $\ldots \ldots \ldots \ldots \ldots \ldots \ldots \ldots$

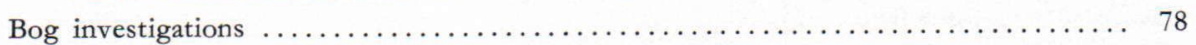

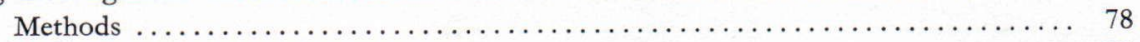

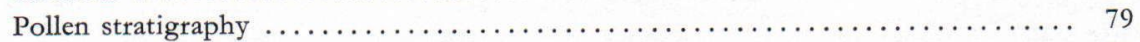

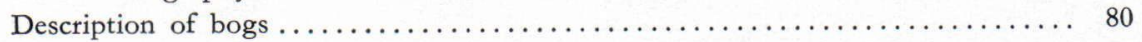

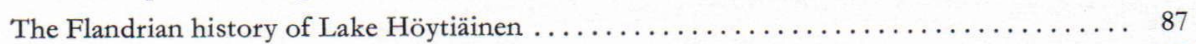

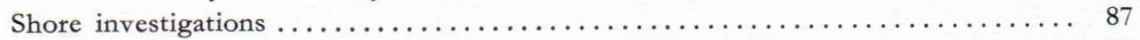

The isolation, Lake Höytiäinen as an independent lake $\ldots \ldots \ldots \ldots \ldots \ldots \ldots$

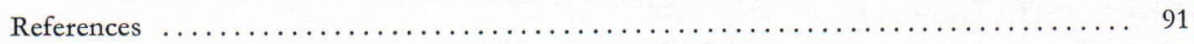

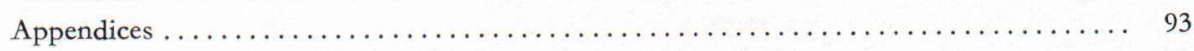




\section{Introduction}

The independent development of a lake on subaquatic land begins after its isolation from the sea. After this the development of a lake is influenced by, apart from the climate, the relationship of its outlet to the differential land uplift, the height of the surrounding thresholds and finally by human operations. It is free of the eustatic movements of the sea level. Undoubtedly, the most remarkable events in the development of Finnish lakes, after their isolation, have been the changes in their outlets due to the tilting of the land.

The purpose of the present study is to explain the Flandrian (= Post-glacial; see West 1963) history of Lake Höytiäinen located in NorthKarelia (eastern Finland), and to study the morphology of the shore-zone which was under water before the draining of the lake in the year 1859. Thus this study seeks to clarify the investigation of raised beaches. Bog investigations were used in the research on development of Lake Höytiäinen as an aid to the shore studies.

At the end of the last century Hackman (1895, 1896) investigated the highest marine limit in North Karelia, but the most significant researches concerning Lake Höytiäinen were made in the 1910's and 1920's. Wilkman (1912) discussed the birth of stump and peat deposits revealed by the draining of Lake Höytiäinen. He also treated this subject in his explanation to the Geological Map of Finland (Frosterus and Wilkman 1917). Helaakoski (1915) surveyed the shore formation of Jouhteninen island on Lake Höytiäinen. The Post-glacial development of this lake was investigated by Sauramo and Auer (1928). In this context mention should also be made of Sauramo's (1928) work, in which he discussed the shore-line displacement in North Karelia. The end moraine of Jaamankangas, which is closely related to Lake Höytiäinen, has been investigated by Repo (1957). The research of Hyvärinen (1966) on Pielis-Karelia with its numerous C-14 datings, is also important in the study of Lake Höytiäinen.

\section{History of lake investigation}

As early as the 19th century raised beaches surrounding lake basins had attracted the attention of researchers, but not until the turn of the century did beach studies begin. Since then, almost all our Quaternary geologists who have investigated shore-line displacements in the region of the Baltic Sea have also to some extent studied the development of our lakes.

Berghell (1898) was the first to refer to the ancient connection between Lake Saimaa and Lake Päijänne. Sederholm (1899) dealt with lakes in the Atlas of Finland. Wilkman's work, mentioned in the introduction, treated the Lake Saimaa area. Ramsay $(1924,1926)$ in his investigations on sea boundaries also dealt with Lake Saimaa and Lake Päijänne. The first to specialize in the development of lakes was Tolvanen, who, on the basis of the morphology of shores, investigated the development of Ancient Päijänne (1922) and Ancient Näsijärvi (1924).

A methodical contribution to lake research was made by Auer's Vanajavesi investigation (1924) in which he connected the study of shore bogs with morphological observations. The same methods were applied later by Sauramo and Auer in their investigations on Lake Höytiäinen (1928), mentioned above in this text. Hellaakoski investigated Great Saimaa (e.g. 1922, 1936) and Lake Puulavesi (1928). Other noteworthy investigators of Great Saimaa were Donner (1957) and Okko (1948, 1965) who worked in the Kuopio region, and Lappalainen, who investigated Southern Saimaa (1962). L. Aario (1936, 1952) studied the development of the southern part of Ancient Päijänne, and R. Aario (1965) widened the study to cover the development of the entire lake system. Alhonen (1967) investigated the Post-glacial history of Lake Kyrösjärvi on the basis of limnic sediments. A new study dealing 
with Lake Vanajavesi has been published by Liisa Simola (1963). The development of the lakes has also been discussed in the commentaries and explanations to geological maps, e.g. Virkkala's investigations on Lake Pielinen (1948) and Lake Näsijärvi (1962).

The development of the greatest basins of the Lake Region is relatively well known although the investigations date from different times. The small number of C-14 datings makes it difficult to draw conclusions about the chronology for the present.

\section{Lake Höytiäinen}

The longitudinal axis of Lake Höytiäinen runs from NW to SE, the area of lake being 285 sq. km and the elevation above sea level 87.5 metres. Its length from Martonvaara bay to Jaamankangas is about 40 kilometers, its greatest width 14 kilometres and its greatest known depth, at the southern end, 50 meters. The shape of the lake has been determined by NW - SE and ENE - WSW orientated fault lines (Frosterus

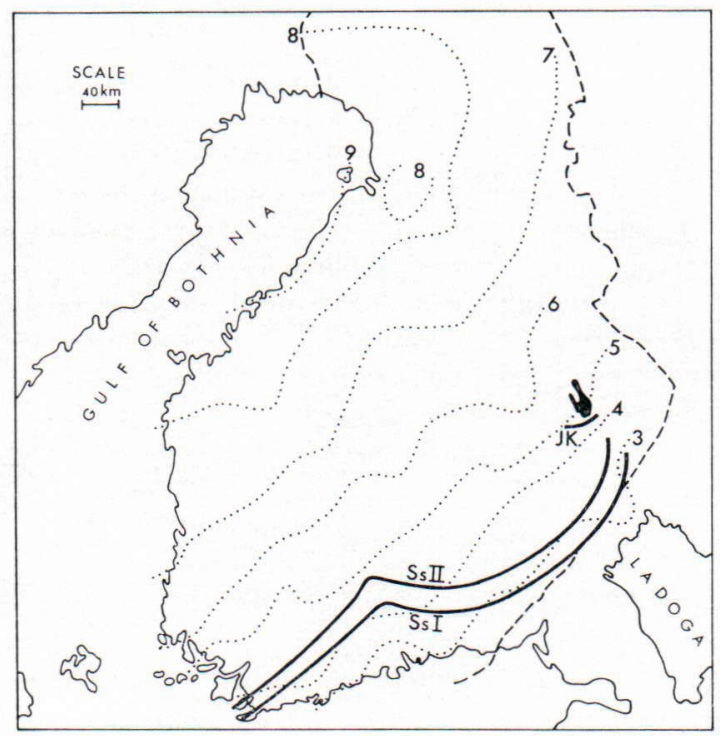

Fig. 1. Map showing the location of Lake Höytiäinen. Isobases for the recent land uplift in $\mathrm{mm}$ per year. According to Kääriäinen (1963). Ss. I, Salpausselkä I; Ss II, Salpausselkä II; Jk, Jaamankangas. and Wilkman 1917, p. 19). The northwestern part of the lake has long bays; the southern part is open with very few islands. (The names of the places mentioned in this study are shown on the appended map, Appendix V.)

\section{Relief, bedrock and surficial deposits}

Lake Höytiäinen is surrounded by hilly terrain rising up to $100-150$ metres. The wide, even dried-up lake bottom, especially at the northern end of the lake, is lower. Before draining in 1859 , the lake was surrounded by abrupt shores. Especially imposing are the Huhmarisenvaara rock at the western side of the lake and the esker island of Jouhteninen, both of which rise by over 50 meters above the water level of the lake. Generally the islands in the lake are low and distinctively longish emphasizing the NW - SE orientated striation of the area.

The bedrock of the area belongs to the Karelian schist zone. The rocks are phyllite and at the northern end mica schist. On the western shore gneiss-granite can be found and in some places amphibolite.

On the shores of the present Lake Höytiäinen wide sand and clay deposits occur which formerly were under water. In some places the old terraces have turned into recent eolian sand (e.g. at Vierevänniemi, Jokiniemi and at the southern end of Jouhteninen). Spreading vegetation, however, continuosly decreases their area. The original Quaternary deposits, with the exception of some eskers and Jaamankangas end moraine at the southern shore of the lake are till. Rough ablation moraine exists on the proximal side of Jaamankangas, but to a great extent the material is glaciofluvial. Closely connected with Jaamankangas is the Kontioniemi esker and also the forementioned Jouhteninen. Vierevänniemi, on the eastern shore of Kontiolahti, has also developed out of a high esker-hill. Kunnasniemi, on the western shore of the lake, is the starting point of an esker extending to Juuka. This esker runs through several islands to the north, up to the 
western shore of Koroniemi where it diverts from Lake Höytiäinen. There are no eskers at the northern end of the lake. Rocky shores are most abundant on the western side of Lake Höytiäinen.

\section{Earlier views on the Late-Weichselian and Flandrian bistory of Lake Höytiäinen}

Observations made on striae prove that the ice cover advanced in North Karelia at least three times during the Late-Weichselian (= Late-glacial; see West 1963) time. The oldest advance came from the NNW forming among others the basin of Lake Höytiäinen in the Karelian schist zone. Another advance came from the northwest (Frosterus and Wilkman 1917, p.p. 30 - 34; Repo 1957, p. 138).

The third and last advance of the ice was so weak that it could not cross the high quarzite ridge in the east, but found its way to lower areas formed by previous erosion (Sauramo 1958, p. 396). It seems that a great deal of ice accumulated in the basin of Lake Höytiäinen, and Jaamankangas was formed in front of it. Its greatest plateaus, as was frequently the case at Salpausselkä, are located at the edges of a wide basin (Repo 1957, p. 142).

According to Repo (1957, p.p. 139 - 144, 266), Jaamankangas and Salpausselkä II (in North-Karelia) are of the same age. They were formed on dry land, for instance, certain plateaus of Jaamankangas seem to be abrasion terraces. According to Sauramo $(1928,1937$, p. 16) Jaamankangas is a glaciofluvial delta which is a part of the so-called Salpausselkä III. The highest plateaus of Jaamankangas are located at such a low level that, if they are primary, the formation is younger than Salpausselkä II (Hyvärinen 1966 b, p.p. 5 - 6).

The retreat of ice from Jaamankangas began, according to Sauramo's varve chronology, at +292 corresponding to about 8000 B.C. (Donner 1964, p. 31). Assuming that the connecting of Finnish and Swedish varve chronologies performed by Sauramo is correct, the precise datings made in Sweden (Fromm 1963) can be used also in Finland. The highest shore at the southern end of Lake Höytiäinen is Yoldia I (Y I) (Sauramo 1937). This marine stage began soon after the Salpausselkä II phase (Donner 1964, p. 33). The highest shore of Lake Höytiäinen is metachronous because not until the time of Sauramo's Y III was the ice front at the northern end of the lake. - Late-glacial events in the research area are schematically presented in Fig. 2.

According to the investigations of Sauramo and Auer (1928, p. 24), the isolation of Lake Höytiäinen took place at about $6800-6900$ B.C. This result is based on a so-

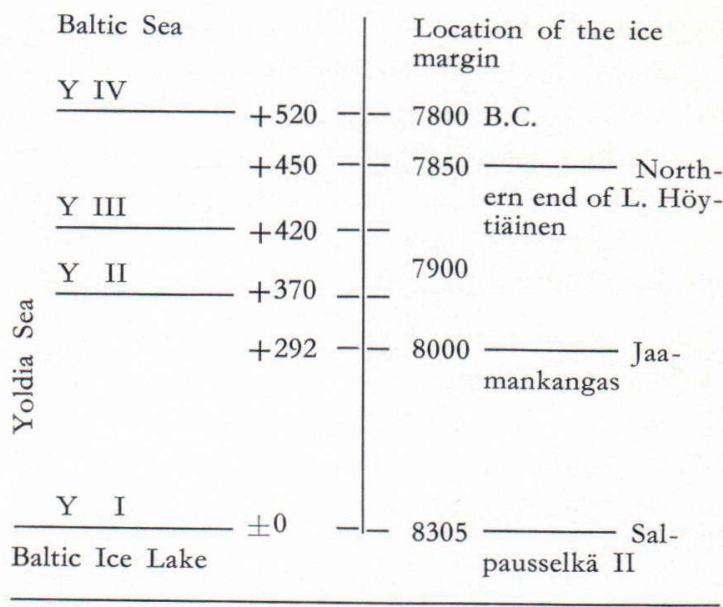

Fig. 2. The Late-Weichselian time at Lake Höytiäinen.

called time-gradient curve, using the marine boundaries dated by varve chronology (see Ramsay 1926) as known shores. According to Sauramo's latest opinion, the isolation of Lake Höytiäinen occured during the youngest stage of the Yoldia Sea, ending in the year 7400 B.C. (Sauramo 1937, p. 20; 1958, p. p. 44, 392).

The isolation threshold was located in the vicinity of Polvijärvi church on the western shore of Lake Höytiäinen. The position of the threshold, in the middle of the NW - SE axis of the lake, decisively influenced the development of the lake because of the tilting of the land. The regression began on the northwestern side of the "tilt-axis» at the threshold and the transgression on the southeastern side. This development continued until the year 1859 when Lake Höytiäinen broke the almost completed dams in a canal between it and Lake Pyhäselkä at Jaamankangas (Palmén 1903, p.p. 65-88). The water level of Lake Höytiäinen dropped by 9.5 metres (from 97 metres above sea level to 87.5 metres above sea level), thus exposing 170 sq.kilometres of dry land, the major part of which was located at the flat northern end of the lake. Regression began in the whole basin. In this investigation, the lake in the year 1859 is also called Old Lake Höytiäinen.

\section{Land uplift}

In Finland, the tilting of the land results from the fact that the rate of land uplift in the surroundings of the northern part of the Gulf of Bothnia is quicker than in the other parts of the country. The present uplift has been investiga- 
ted thoroughly. According to Sirén (1951), the uplift at the southern end of Lake Höytiäinen is $5.5 \mathrm{~mm}$ and that at the northern end $6.5 \mathrm{~mm}$ annually. According to the readings of the precise levelling made by Kääriäinen (1953), the annual uplift at the southern end is $3.5 \mathrm{~mm}$ and at the northern end $4.5 \mathrm{~mm}$. It should be noted, however, that at that time, the levelling network did not extend to Lake Höytiäinen but the isobases were drawn parallel to the lines of Sauramo's isobases describing the different stages of the development of the Baltic Sea (Kääriäinen 1953, p.p. 64 - 70). According to the latest precise levellings (Fig. 1), the southern end of the lake rises by $4.6 \mathrm{~mm}$ and the northern end by $5.4 \mathrm{~mm}$ a year (Kääriäinen 1963). According to all available investigation results, Lake Höytiäinen is tilting annually by 1 millimeter. The isobases are mainly SW - NE orientated.

The rate of land uplift just after the Weichselian glaciation was quicker than nowadays (e.g. Sauramo 1939), but nothing certain can be said of the rate of annual uplift during different times.

\section{Shore investigations}

Shore formations are created by wave action, ice and wind. The combined effect of these forms a type of shore that is decisively dependent on local environment, such as the openness of the shore, the depth of the water and the profile of the shore but primarily the surficial deposits. Furthermore, the development of a shore is influenced by its position, in other words, whether it is located at rising or sinking water level. In narrow inland waters the shaping of shores by ice is a result of the expansion of the ice, the pressure of pack ice being only slight (see Hellaakoski 1922; Leiviskä 1913).

\section{Methods}

The shore profiles which are presented in Appendices $I$ and $I I$ were prepared on the basis of levelling readings.
The height of the shore-line was determined on each shore as the average of the heights of three neighbouring typical ice-pushed boulders. The analysis of the sediments was made in the field and partly in the laboratory by sifting.

\section{The shore types of Old Lake Höytiäinen}

In this investigation attention is paid, primarily, to such points of the shore-line where morphological transitions have actually occured, since these shores are most suitable for the investigation of raised beaches. The classification of shore types presented below is based on wave action. The same classification can also be applied to shore formations created by ice expansion because they are also dependent on formations resulting from wave action. So, for instance, the marks of the ice expansion are clearest and most permanent on erosion shores from which the waves have washed away all fine material, and the pressure of the ice has been directed against the exposed rocks (Hellaakoski 1922). - Furthermore, the classification is based on surficial deposits.

1. Erosion shores in glaciofluvial material

2. Erosion shores in till

3. Accumulation shores

4. Morphologically disappeared shores

1. Erosion shores in glaciofluvial material. A great deal of loose material is to be found on esker shores. The profile of the shore corresponds to that a typical abrasion shore. Its characteristics are: a steep cliff and a sloping terrace ending at a distal slope of the terrace. The movements of ice have grouped the rocks on the terrace, the biggest rocks being piled as a rampart under the cliff and the smaller stones pressed firmly in the terrace. In places where there are large amounts of rocks they have accumulated in shapeless piles under the cliff. The terrace here generally ends at a distal slope, located approximately at the same depth in each place in the lake. The distal slope is composed of sand as, for instance, on shores 25, 26 and 29 of Jouhteninen. In some cases the stones have been so abundant that the seesawing motion of the ice on the terrace has driven the rocks deeper into the water where they form a cliff-like distal slope of the terrace (Fig. 4). The sedimentation of sand and fine material has only begun at greater depths. Examples of this are shores 6,7 and 10 of Jaamankangas, shores 13 and 14 of Kontioniemi and shores 21, 22 and 23 of Vierevänniemi.

The investigation is obviously handicapped by the fact that all eskers and Jaamankangas are located on the side of the lake where transgression has occured. Therefore, Lake Höytiäinen does not offer any opportunities for 


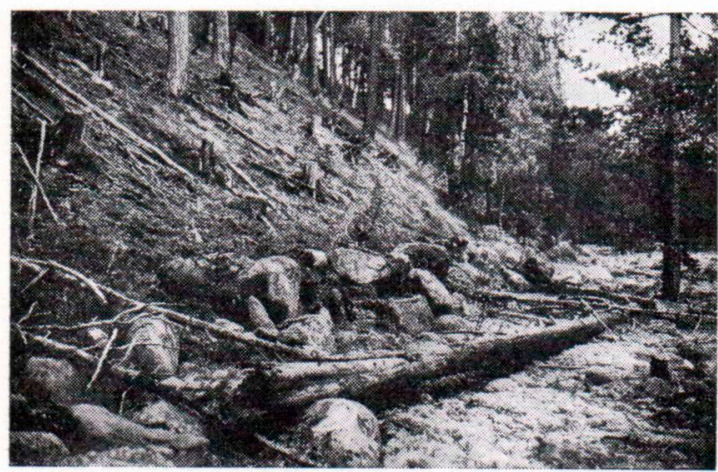

Fig. 3. Jouhteninen. An abrupt erosion cliff of Old Lake Höytiäinen with continuous ice-rampart at the base. Shore profile 29.

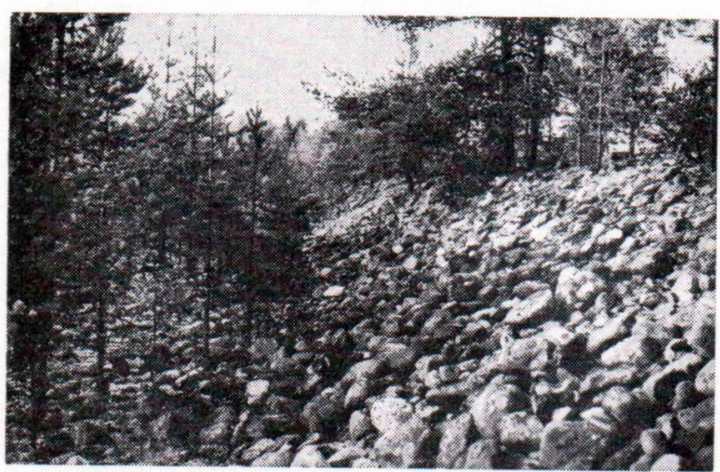

Fig. 4. Jaamankangas. A distal slope of the terrace of Old Lake Höytiäinen between shore profiles 3 and 4 .

comparing the differences between esker shores open to erosion in regression and transgression areas. Furthermore, the widest open places of Lake Höytiäinen are at the southern end of the lake while the shores in the regression area are relatively closed. Since erosion, because of transgression, has reached higher and higher and since the vast area of water has given it strength, shores belonging to this type have developed exceptionally imposing shapes.

Shores falling into this category are: $4,6,7,8,10$, 12, 13, 14, 15, 16, 21, 22, 23, 25, 26, 27, 28 and 29 (Fig. 3).

2. Erosion shores in till. The most characteristic shores of this type are similar to those mentioned above. Such are e.g. shore 19 of Kontionlahti and shore 24 of Vierevänniemi which were generated in a thick till by open water. In regression areas shores of this type are obscure. In these areas the cliffs seldom reach a height of one meter (shores 32 and 33). An incoherent ice-rampart is often the only proof of their location. In transgression areas the shores are also obscure in narrow places (e.g. shores 1 and 2 of Kunnaslahti). The till cover of the bedrock on the shores of Lake Höytiäinen is generally so thin that a cliff could not be formed. It is true that erosion can also produce a cliff in rock as, for instance, in Varparanta near shore 30. From friable mica schist erosion, supported by weathering due to frost, has removed rocks which form a terrace. Schistose veins and the shore-line are parallel.

Shores falling into this category are: 1, 2, 17, 18, 19, 24, 30, 31, 32 and 33.

3. A c cumulation shores. In transgression areas erosion has been predominant. The surf has driven material only into some closed bays and formed ramparts on the shore. The biggest sand bars are over one meter in height (e.g. shore 20 of Vierevänniemi). A common feature of accumulation shores created by waves is the absence of stones. The profile of the shores is sloping. An accurate determination of the height of the shoreline on accumulation shores is impossible. The weakly developed accumulation shores in the regression area have often been completely covered and destroyed by vegetation.

In Jaamankangas some special cases representing this type of shore can be found (shores 3, 5 and 11). At the mouths of small bays there are banks containing such rough material that the only explanation to this kind of accumulation is the expansion and pressure of ice. Below the banks the morphology of these shores is similar to that of neighbouring erosion shores.

Shores of this type are: $3,5,9,11$ and 20 .

4. Morphologically disappeared $\mathrm{s}$ h o r e s. In surprisingly large areas the shore marks of Old Lake Höytiäinen have disappeared almost completely within the last 100 years. Such areas are most frequently located on the narrow till shores in regression areas. Numerous rock belts on the slopes can easily be misinterpreted. Also in these areas subaquatic sedimentation has taken place and therefore, by investigating the surficial deposits, it is possible to determire the boundary between the original slope and the sediments assorted by abrasion. In regression areas this boundary naturally lies higher than the shore-line of Old Lake Höytiäinen.

\section{The suitability of the shores for the investigation of raised beaches}

The investigation is an attempt to determine the altitude of the shore-line with the aid of 
beaches. This altitude corresponds to the height of the base of the ice-rampart or, where that does not exist, the height of the base of the cliff. The altitude of the shore-line is generally the same as the mean high water level which in the Finnish lakes is about 0.5 metres above the mean water level (Hellaakoski 1922; Tolvanen 1922; Varjo 1964). In investigations concerning the lakes of the Heinola region it was found that the height of the ice-rampart varied substantially on shores with large amounts of stones. The height of the base of a morphologically distinct ice-rampart might correspond to the low level of water in the winter (Saarnisto 1965, p. 67).

The altitude of the shore-line of Old Lake Höytiäinen varies 0.5 metres. The difference between the extreme values is over 1 metre. The highest shore-line is located on the open and practically stoneles southern shore of Jouhteninen (97.6 metres, shore 28). Low shore-lines can be found e.g. on the stony slopes of Kontiolahti (96.5 metres, shore 19) and Varparanta (96.4 metres, shore 31). An accurrate determination of the altitude of the shore lines with raised beaches is not possible because they have become deformed to a greater extent than the shore of Old Lake Höytiäinen. The average error of observations is probably at least 1 meter.

On the shores of Old Lake Höytiäinen the elevation of the shore-line can only be determined on shores falling into categories 1 . and 2 . The suitability of esker shores which contain much fine material for the investigation of raised beaches is impaired by the fact that in places where many shores coincide vertically, most often only the yongest is visible. It erodes the old shores above it and accumulates over the lower shores. This has happened e.g. on shore 29 of Jouhteninen where the slope runs with the same abruptness from the base of the cliff to the top of the esker up to a height of 30 metres (see Hellaakoski 1928, p. 6).

In this investigation special attention is paid to any possible shore marks appearing in the nine meter high zone which emerged at the draining of the lake in 1859. According to Sauramo and Auer (1928, Appendix II), the last marine boundaries preceding the isolation of Lake Höytiäinen, and above all, the isolation shore of the lake fall within this zone on the southeastern side of Polvijärvi threshold. Most shores relevant to this investigation are of type 1 . Therefore the investigation throws light on the preservation of raised beaches under conditions of transgression in environments favourable to the development of shores.

Shore profiles show that the shore of the year 1859 is morphologically dominant. In the study of raised beaches the distal slopes of the terrace on some shores might confuse the determination of the elevation of the shore, especially if the supra-aquatic part of the shore is morphologically weaker than the distal slope of the terrace, as for instance on shores 3 and 5. However, the material of the distal slope distinctively differs from the material of the cliff and no icerampart at the base of the distal slope of the terrace is to be found. Fig. 4 shows how the stones accumulated by the ice on a distal slope have fallen down from the upper parts. In three profiles (11, 15 and 26) low cliffs near the present water level can be identified as shores, but no shore-line can be described on these grounds.

The formation of the shore of Old Lake Höytiäinen have destroyed almost all lover shore marks. Naturally, during the progress of transgression the shore-line at some stage was located in every part of the zone investigated at the southern end of the lake providing that the isolation shore there is located at the present water level (see Sauramo and Auer 1928). However, neither the isolation shore of Lake Höytiäinen nor any other shore-lines of the lake prior the year 1859 can be discovered by the morphological investigation of the shores.

\section{Marine raised beaches in the basin of Lake Höytiäinen}

Above the 1859 shore the morphology of the slope shows features that can be considered as 
products of erosion. The most distinctive marks are located on the same slopes as those on which the shore of Old Lake Höytiäinen is most distinctive. A list of the latest observations is presented below. The same observations are also shown on the appended map.

New observations (levelled from the water level of Lake Höytiäinen)

1. Jaamankangas (shore 10). Gradually sloping erosion cliff, shapeless ice-rampart at the base. 103,6 metres.

2. Jaamankangas (shore 8 ). Gradually sloping erosion cliff, shapeless ice-rampart at the base. 106,3 metres.

3. Jaamankangas (shore 4). Abrupt erosion cliff, coherent ice-rampart at the base. The width of the terrace has been eroded to less than 10 metres. 105,7 metres.

4. Kontioniemi (shore 14). Abrupt erosion cliff, shapeless ice-rampart at the base. The width of the terrace has been eroded to less than 10 metres. 106,3 metres.

5. Kontioniemi (shore 15). Gradually sloping erosion cliff, shapeless ice-rampart at the base. 106,3 metres.

6. Vierevänniemi (shore 23). Abrupt erosion cliff, coherent ice-rampart at the base. 106,3 metres.

7. Martonvaara (by barometer). On the slope of the hill a low cliff and below it a sand terrace. 113,5 metres.

Lower, another cliff, the height of which is about 1 metre, and below it a sand terrace. 103,5 metres.

Previous observations are shown on the appended map. The oldest measurements were made by Wilkman (1912) with the aid of a barometer. In part they are based on the erroneous elevation of Lake Höytiäinen: 85 metres. To the measurements, used in the present investigation, 2 metres have been added. The numbering of the appended map does not correspond to Wilkman's numbering. The most abundant information concerning the study of raised beaches is included in Sauramo's investigation (1928). The elevations of the shore lines have been levelled. The numbering is similar to that of Sauramo. In a posthumous paper, published by Sauramo, Ramsay gives a number of shore observations from different parts of Finland (Ramsay 1931). The numbering corresponds to that of Ramsay.
The above investigations also contain some shore observations below the 1859 shore line. It has previously been emphasized that the formations of the shore of Old Lake Höytiäinen are morphologically dominant in the zone which emerged at the draining of the lake. Therefore, the observations made below the 97 meter level have been omitted as uncertain.

The description of synchronous shore lines based only on morphological observations is uncertain but the marine stages preceding the isolation of the basin of the Lake Höytiäinen are so few and the observations group themselves into such distinct zones that the description of the shore lines shown in the appended diagram (Appendix VI) is well grounded. They are in accordance with the shore lines of the same region described by Sauramo (1937, p. 17, 1958).

\section{Bog investigations}

Auer (1924) was the first in Finland to take advantage of bog investigations in his study of the Post-glacial history of Lake Vanajavesi. L.von Post (1909) proved that the boundary between limnic and telmatic sediments - the limno-telmatic contact - gives the approximate level of low water in a basin (see Auer 1924, p.p. 136 - 137). The stratigraphy of shore bogs is not always complete because the variations in the water level easily turn the conditions in the shore zone favourable to either erosion or sedimentation. This possibility is minor in limnic sediments, but the determination of different water levels on these grounds can only be done very approximately.

\section{Methods}

The elevation of the bogs was determined by using two barometers and a topographic map, scale 1:100 000 . Measurings were started from the water level of Lake Höytiäinen which is determined daily by the Hydrological Bureau. The time between the start and completion of a measuring was less than five minutes. 
Samples were taken by a Hiller sampler. The sediments were usually identified in the field and check-ups were made microscopically.

Pollen samples were prepared by the KOH-method and, if necessary, siliceous components were removed by HF treatment (see Faegri and Iversen 1964). All preparations were made in glycerol and dyed by safranin. In the analysed samples, 150 tree-pollen (AP) grains were counted (including Corylus). Some samples of older minerogenic sediments were so poor in pollen that counting was limited to 100 . The results of the analysis are shown in column diagrams. As to the AP/NAP ratio, tree-pollen includes pollen of shrubs, but NAP does not include aquatic pollen.

In making the diatom preparations the sample was kept in a $30 \% \mathrm{H}_{2} \mathrm{O}_{2}$ solution at a temperature of $+50^{\circ} \mathrm{C}$ for about 24 hours. Diatom scales were separated from the mineral material by flushing and decanting. Hyrax was employed as mounting material. 100 individuals were identified in each preparation. In the identification of diatoms the works of Hustedt $(1930,1930$ - 64) and Foged (1964) were referred to and in ecological questions the investigations of Maj-Britt Florin (1946), Astrid CleveEuler (1946), Mölder (1943) and Tynni (1966) were consulted.

\section{Pollen stratigraphy}

In the determination of the age relationships of the litostratigraphic changes pollen analysis was employed. The pollen diagrams were divided into the forest historical zones according to Donner (1963, also 1951, 1966) and Sauramo (1958, also 1949). The dating of pollen stratigraphy is checked by C-14 determinations made during recent years in different parts of Finland. In the southern parts of Finland the zones are mainly synchronous (Donner 1963, p. 22) yet so that they get slightly yonger eastwards and northwards, e.g. the boundary between zones IV and $\mathrm{V}$ in eastern Finland is presumbly 300 years younger than that in southern Finland (Donner 1966 , p. 19). Donner has also proved (1966, p. 21) that in the terms of pollen chronology only Post-glacial sediments are comparable. The maxima of non-tree pollen found in the early Post-glacial sediments representing the first stages of local vegetation after the deglaciation and/or emergence of the area and without any chronological value is often erroneously con- sidered to be of the same age with the Lateglacial Yonger Dryas, characterized by the abundance of NAP.

The oldest forest historical zone that can be identified in the investigated area is the first Post-glacial zone IV. In the lower part of this zone, plenty of non-tree pollen is to be found. The retreat of ice from Jaamankangas began about 10000 years ago. This was the beginning of zone IV at Lake Höytiäinen. The age of the zone boundary IV/V is about 8500 years which, according to the classification made by Hyvärinen (1966) on the basis of the maximal occurrence of different trees, corresponds to the boundary between Betula and Pinus zones. According to Tolonen (1967, p. 363), the age of the zone boundary IV/V in northern Karelia is the same as in South Finland, i.e. about 8800 years (e.g. Donner 1966). The dating corresponds to the beginning of the Post-glacial Hypsithermal interval (Deevey and Flint 1957). The zone boundary V/VI can be distinguished in the pollen composition because at this point Pinus decreases while Betula increases, the curve of Alnus rises and the amount of rare deciduous trees increases. The age of the zone boundary is about 8000 years (see C-14 datings in South Finland: Donner 1966, p. 20, about 7800 years; Virkkala 1966, p. 238, about 8000 years; Alhonen 1967 , p. 23, about 8000 years and in northern Karelia: Tolonen 1967, p. 365, about 8000 years).

In Finland, the zone boundaries between zones VI - VIII cannot be determined even in those places where the appearence of rare deciduous trees has been more abundant than in northern Karelia (see Donner 1963, p. 6). The only chronological fixing point in northern Karelia is the immigration of Picea which took place already in the middle of the Hypsithermal interval, about 5000 years ago (Hyvärinen 1966, p. 18, Tolonen 1967, p. 366).

The zone boundary VIII/IX can be distinguished in pollen stratigraphy because rare desiduous trees disappear and the proportion of Pinus increases while that of Betula decreases. 
The boundary is not as clear as the zone boundaries IV/V and V/VI (see Donner 1966). The age of the zone boundary in South Finland is about 2500 years (Sauramo 1958, p. 44; Alhonen 1967, p. 23). Tolonen (1967, p. 368) is of the opinion that the boundary in northern Karelia is of the same age, even though it is uncertain. The age of the boundary coincides with the end of the Hypsithermal interval.

The samples belonging to zone IV, investigated at Lake Höytiäinen, are often composed of clay or other minerogenic material. Heinonen (1957) has proved that till contains abundantly secondary pollen, and because of this, the pollen analysis of Late-glacial clays is not reliable (Sauramo 1958 , p. p. 39 - 41). In younger minerogenic sediments, the abundant primary pollen conceals the possible secondary pollen (see also L. Aario 1940; Donner 1951). In the lower parts of the profiles investigated at Lake Höytiäinen secondary pollen plays some role but already during zone IV their role has become non-existant due to the great density of pollen in the preparations.

The variations of tree pollen in the samples correspond to the general description of the zones. The rise of Alnus's curve begins already within zone $\mathrm{V}$ and its immigration cannot always be regarded as zone boundary V/VI. Of the scant rare deciduous trees Tilia should be mentioned. Its discontinuous curve often begins shortly before Picea's immigration. Auer (1928) was the first to point out that the immigration of Picea to Finland came from the east. Hyvärinen's C-14 dating, mentioned above, proves that Picea began to immigrate to Lake Pielinen 5000 years ago. The area Hyvärinen investigated is located less than 50 kilometres from Lake Höytiäinen and therefore the immigration of Picea was most probably almoust simultaneous in these two areas. The immigration of Picea could be distinctively identified in each investigated bog and therefore it is suitable for dating.

The occurrence of NAP and shrub pollen at Lake Höytiäinen can be seen in the diagram illustrating the Kiiskisensuo bog (Fig. 6). NAP was very abundant immediately after the retreat of the ice. When the development of vegetation became subject to the fluctuations of the Postglacial climate the occurrence of NAP declines. Later, non-tree pollen may reach a new maximum when indicating a shore. These maxima are generally composed of Gramineae and $\mathrm{Cy}$ peraceae. There is only scant aquatic pollen to be found in the investigated bogs.

\section{Description of bogs}

$\mathrm{Ki}$ iskisensuo bog (diagram 1., Fig. 6) is located at the northern end of Lake Höytiäinen and has a direct connection with the lake. The lowermost clay deposits goes down to 7 metres. Possible varves cannot be distinguished. The stratigraphy shows the location of the bog in a regtession area (see Sauramo 1958, p.p. $35-36)$. The water level cannot be accurately determined by stratigraphy. The upper part of the clay-mud contains remains of Equisetum. The highest telmatic deposit ends at a depth of 160 centimetres. It is loose mixed peat containing pieces of Carex, Equisetum, Phragmites and Sphagnum and has probably accumulated on the shore.

The zone boundaries IV/V and V/VI are clear but the boundary VIII/IX is uncertain. The limnotelmatic contact dates from the beginning of zone VI. The final drop in the water level did not take place until the middle of the Hypsithermal interval, before the immigration of Picea. The sedimentation of Eriophorum-Sphagnum peat occurred at the same time.

A diatom analysis was made of the clay and clay-mud of Kiiskisensuo bog. The results of the analysis are presented in Appendix III. The diatom flora does not include any salt-water species even though the lowest

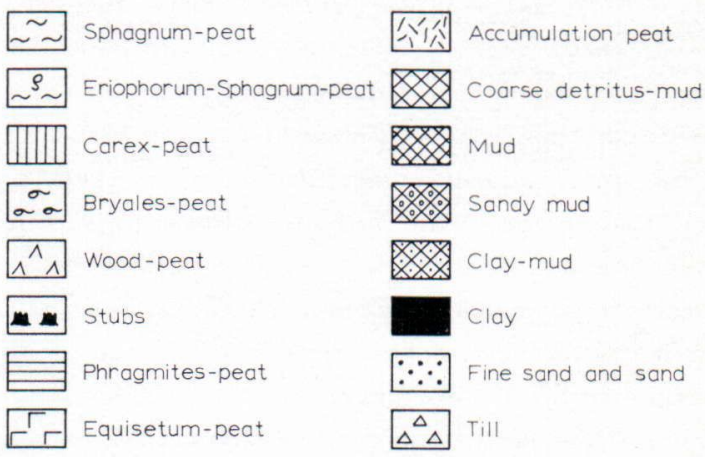

Fig. 5. Explanation of the symbols. 

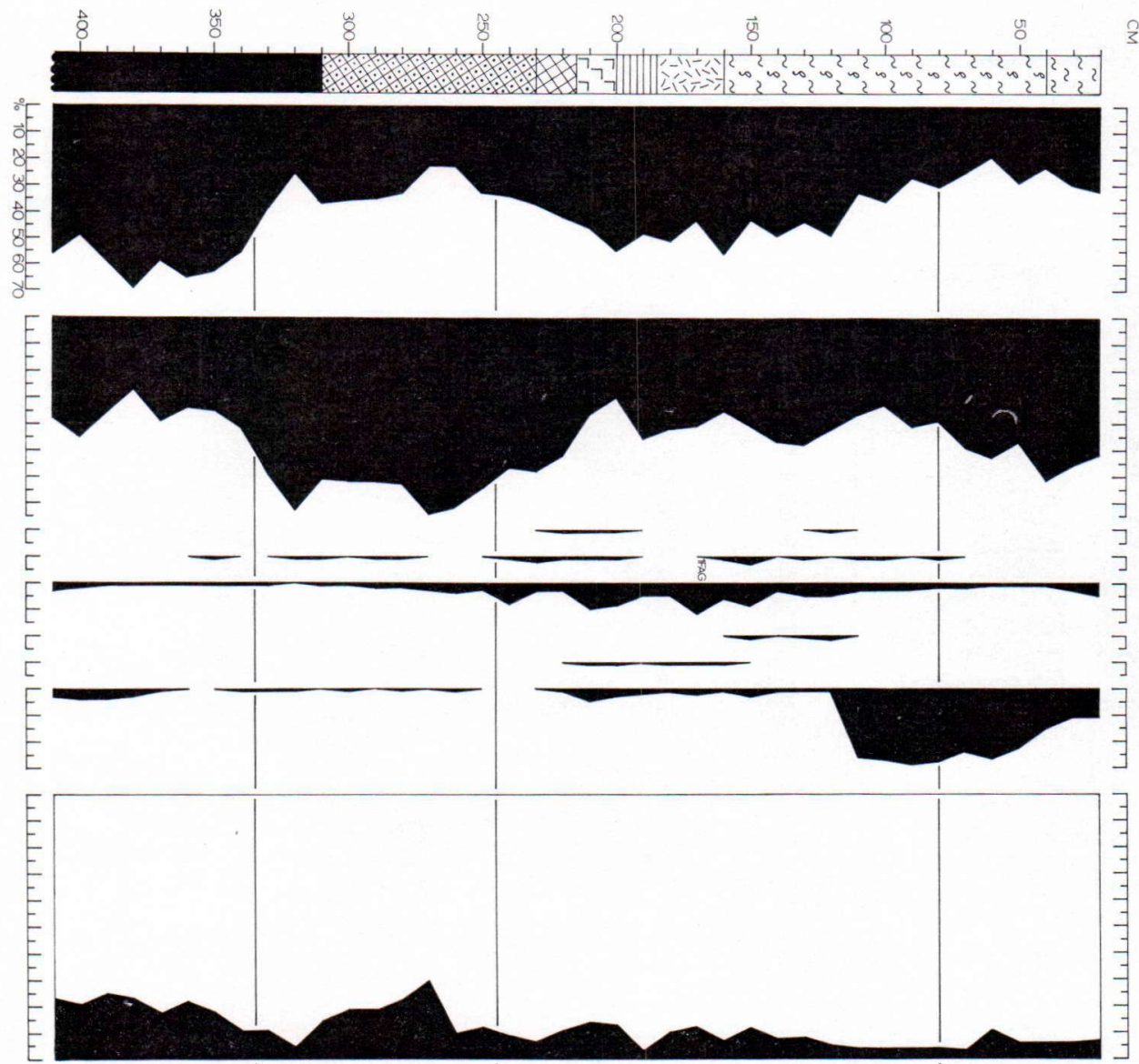

PINUS

BETULA

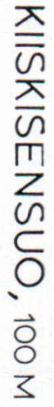

CORYLUS

ULMUS

ALNUS

TILIA

QUERCUS

PICEA

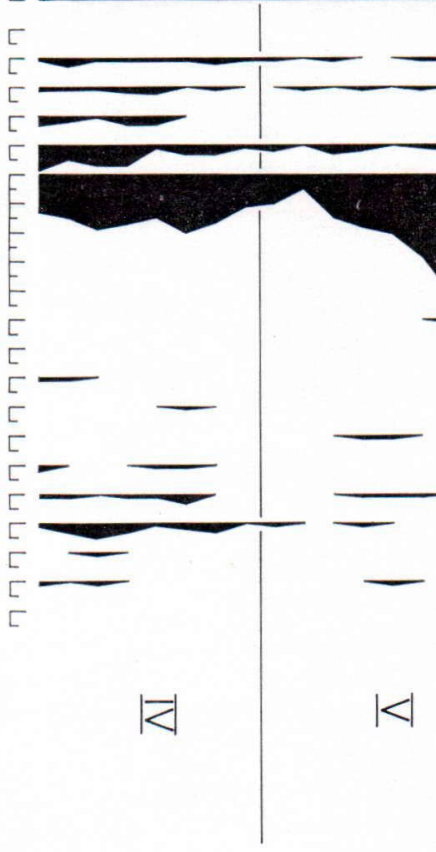

Fig. 6. Pollen diagram 1.

HIPPOPHAE JUNIPERUS SALIX ERICALES CYPERACEAE GRAMINEAE

ARTEMISIA

CARYOPHYLLACEAE CHENOPODIACEAE COMPOSITAE CRUCIFERAE PLANTAGO RANUNCULACEAE ROSACEAE RUMEX SAGITTARIA DROSERA

$|\bar{x}|$

$$
\text { 风 }
$$




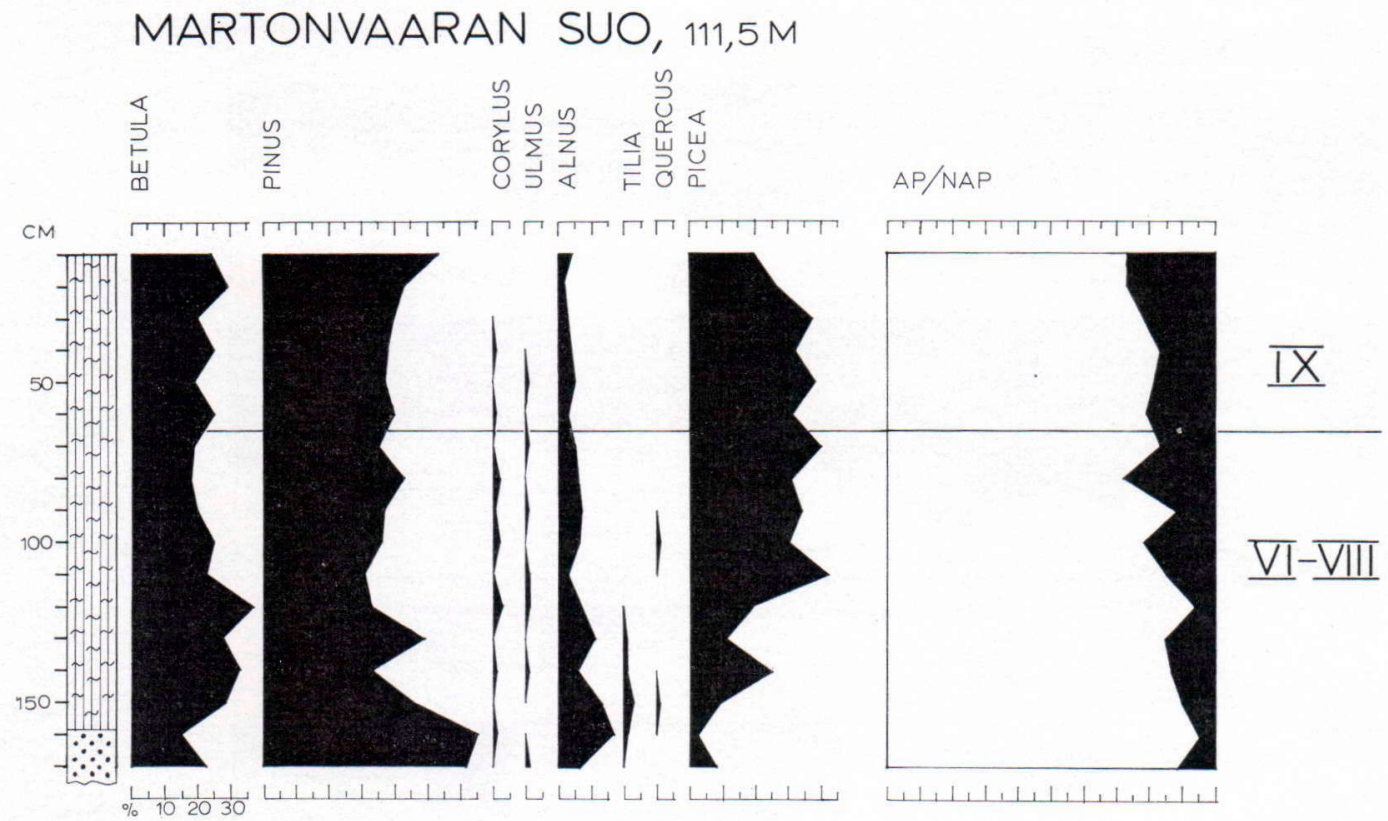

Fig. 7. Pollen diagram 2.

\section{VIKLINSUO, 98,5 M}

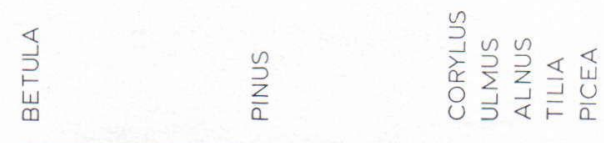

AP/NAP

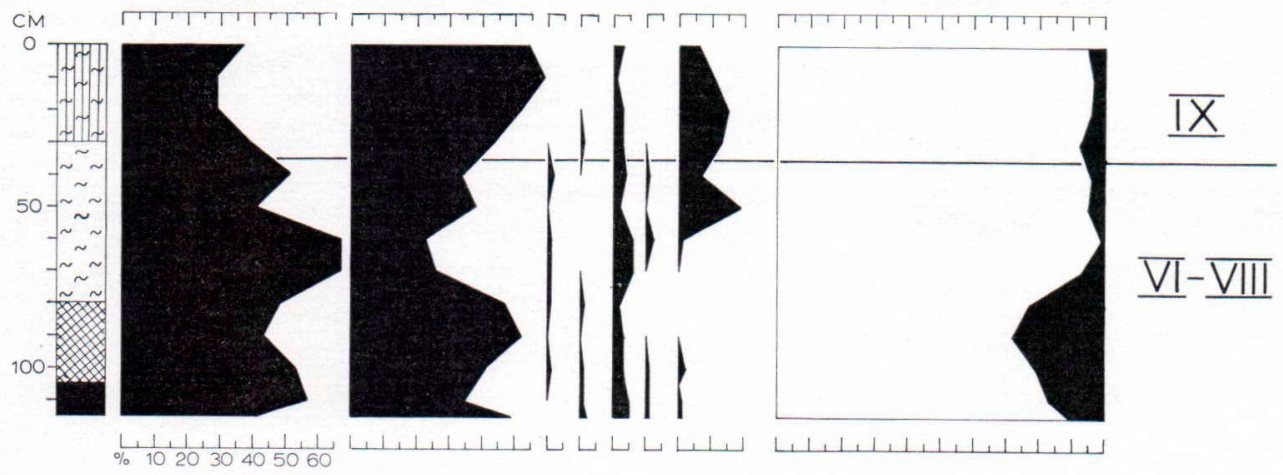

Fig. 8. Pollen diagram 3.

deposits were formed on the bottom of the Yoldia Sea. The same observation has also been made in the Kuopio region by Donner (1957, p. 13). He points out thac this results from the fact that the area was connected with the sea through shallow and narrow waters and therefore the saltwater did not reach far inland, especially since the melting ice produced fresh water. Not even at Lake Pie- linen have saltwater diatoms been found (Hyvärinen 1966). As far south as Askola in South Finland the Yoldia Sea was almost fresh and the flora caracterizes rather a great lake (Tynni 1966, p. 68).

When comparing the variations of the diatom flora of Kiiskisensuo bog with the corresponding flora of Vattusuo bog at Lake Pielinen (Hyvärinen 1966, p. 25), many 


\section{KONNUNSUO, 98,5 M}

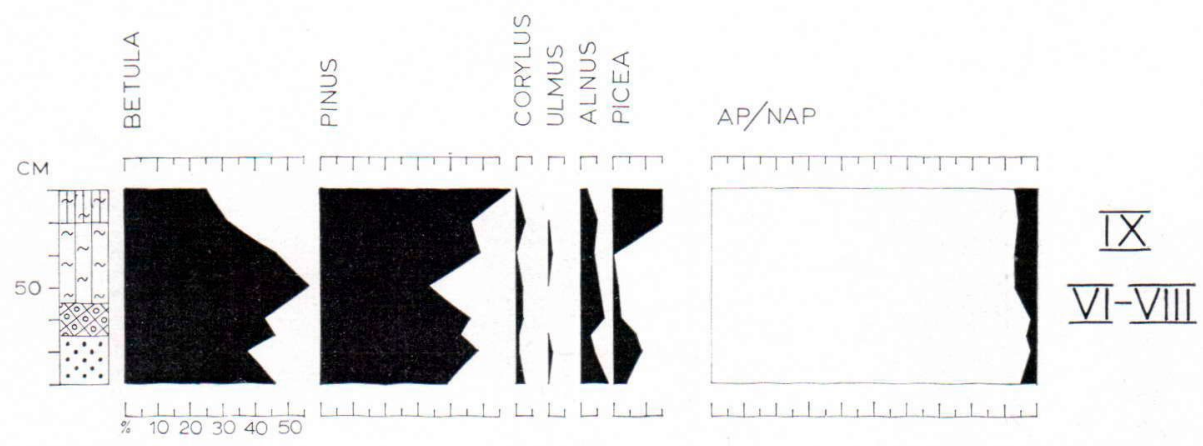

Fig. 9. Pollen diagram 4.

similarities can be seen. A maximal occurrence of pelagic Melosira islandica ssp. helvetica in both regions dates from zone IV (the NAP and Betula zones of Hyvärinen). The maximal occurrence of Fragilaria in both areas dates from the beginning of zone V. Even after this the development of the diatom flora shows similar variations. Diatoms are usually littoral fresh water forms. The development in these neigh bouring areas has been very much alike. Regression has occured in both basins. The diatom flora does not indicate the isolation of the lake.

Martonvaara bog (diagram 2., Fig. 7). On the southwestern slope of Martonvaara hill there is a cliff (113.5 metres) and below it a plain terrace. The bog is located on the terrace, its size being $50 \times 100$ metres. The area started to become embogged only after the zone V/VI even though the place had emerged much earlier. This is indicated by earlier peat sediments on lower bogs.

Viklins u o bog (diagram 3., Fig. 8) is a vast shallow bog in the regression area. The sedimentation of mud discontinued a short time before the immigration of Picea. The boundary between mud and terrestric peat lies at an elevation of 98 metres above sea level. The regression of Lake Höytiäinen on Viklinsuo bog since the middle of the Hypsithermal interval was only about 1 metre. The location of the bog near the tilt-axis makes this credible. - The maximal occurrence of NAP indicatng the shore consists of Gramineae.

Konnuns u o bog (diagram 4., Fig. 9) is located at the tilt-axis on the eastern shore of Lake Höytiäinen at an elevation of 98.5 metres. Mud, containing fine sand, formed during zone VI. This obviously proves that the water level in Lake Höytiäinen was at a higher level than the outlet threshold, providing there has not been any other threshold damming the water between the lake and Konnunsuo bog.

$\mathrm{Huhmarinen} \mathrm{bog} 1$ and 2 (diagrams 5. and 6., Figures 10. and 11). On the western side of Huhmarisenvaara, about 8 kilometres to the southeast of the isolation threshold, there is a bog, a part of which was submerged before the year 1859. A 1 metre high cliff in the peat shows the location of the 100-year-old shore. Sample 1 was taken from that part of the bog which was not submerged. On the bottom, the peat lies directly on mineral material, and there are no limnic sediments between them. This proves that the place where the sample was taken was a forest which later became embogged. The deepest place in the bog is elsewhere.

Sample 2 was taken below the 1859 cliff about 100 metres away from the previous sample. The elevation of the bog is about 95.5 metres. This place emerged at the end of zone IV. At that time water was below the 94.5 metre level. Soon after the zone boundary V/VI before the immigration of Picea the place was submerged under a transgression. The maximal occurrence of Alnus shown in diagram 5 probably refers to this. After the bog had become submerged, erosion could not have been extensive because the place is so closed. On the other hand, no sedimentation occurred after the rise of the water and therefore the stratigraphy shows a hiatus before the recent surface.

Kunnaslahti bog (diagram 7., Fig. 12). This bog is located below the shore of Old Lake Höytıäinen and a part of it is field. The peat is partly covered by sand. The peat, containing wood lying at a depth of 100-130 centimetres, contains sticks of Betula nana. Emergence occurred during zone IV. At that time the water level was under 91.5 metres which made the sedimentation of terrestric peat possible. The bog became flooded under a transgression after the zone boundary V/VI. 
HUHMARISEN SUO 1, 97,5 M

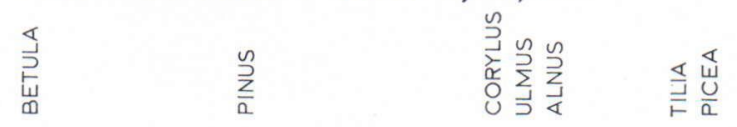

AP/NAP

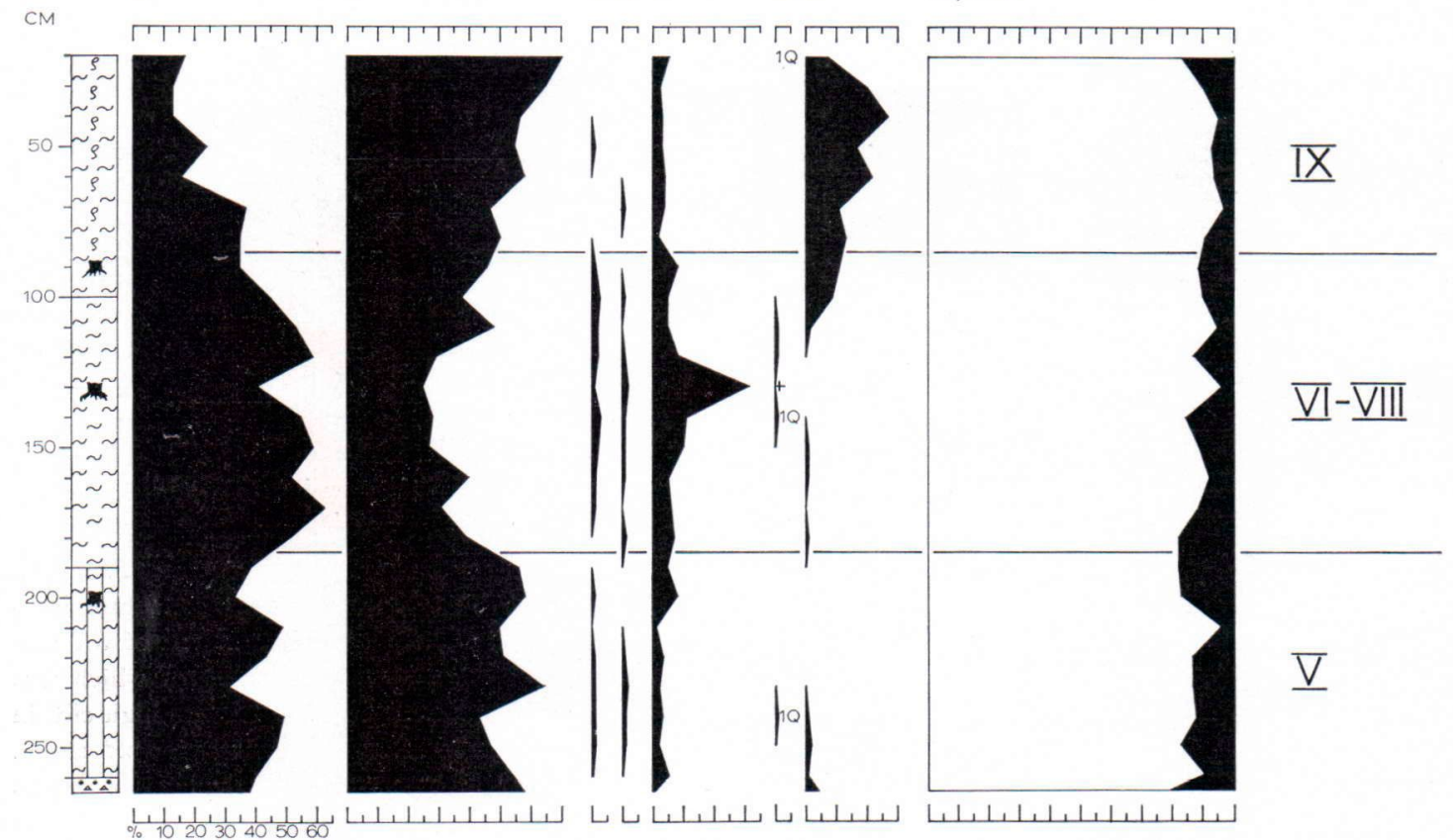

Fig. 10. Pollen diagram 5.

HUHMARISEN SUO 2, 95,5M

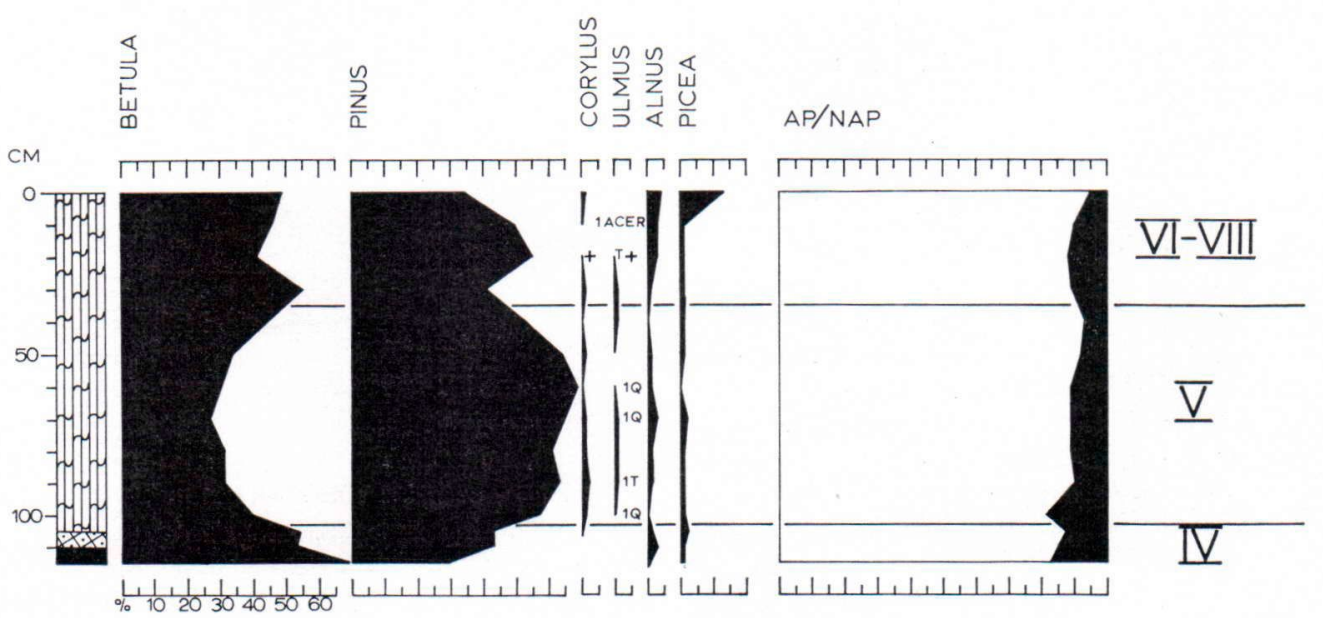

Fig. 11. Pollen diagram 6. 
KUNNASLAHDEN SUO, 93M

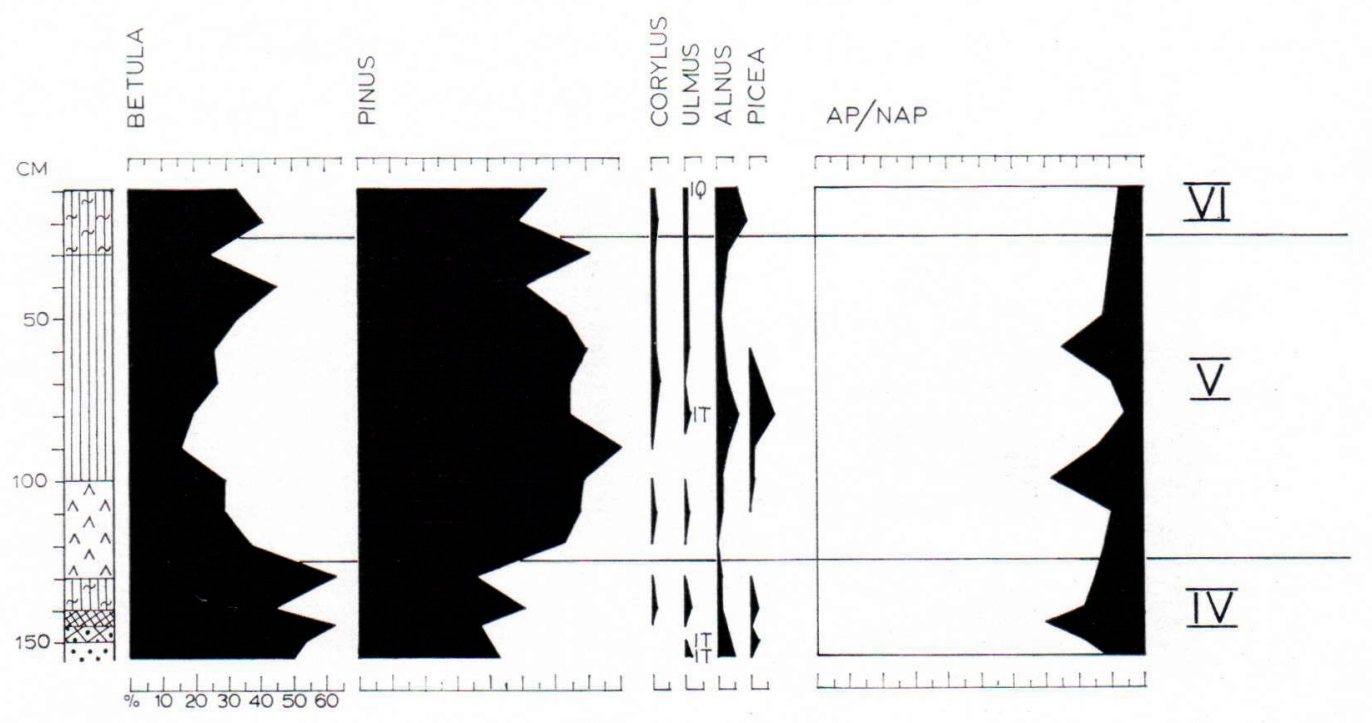

Fig. 12. Pollen diagram 7.

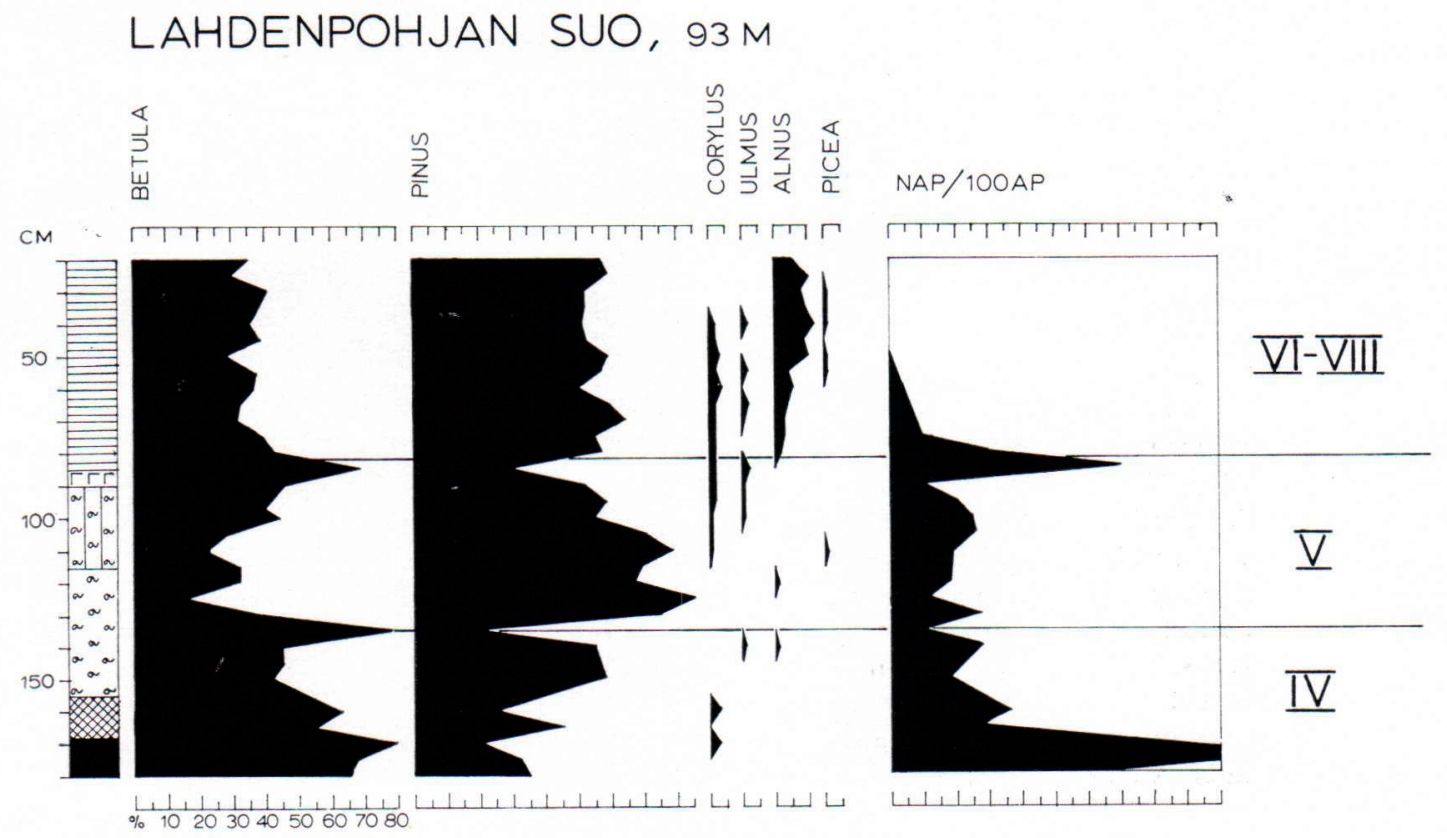

Fig. 13. Pollen diagram 8. (Sauramo 1958, Tp. 392, Fig. 134). 


\section{VIEREVANNIEMI}

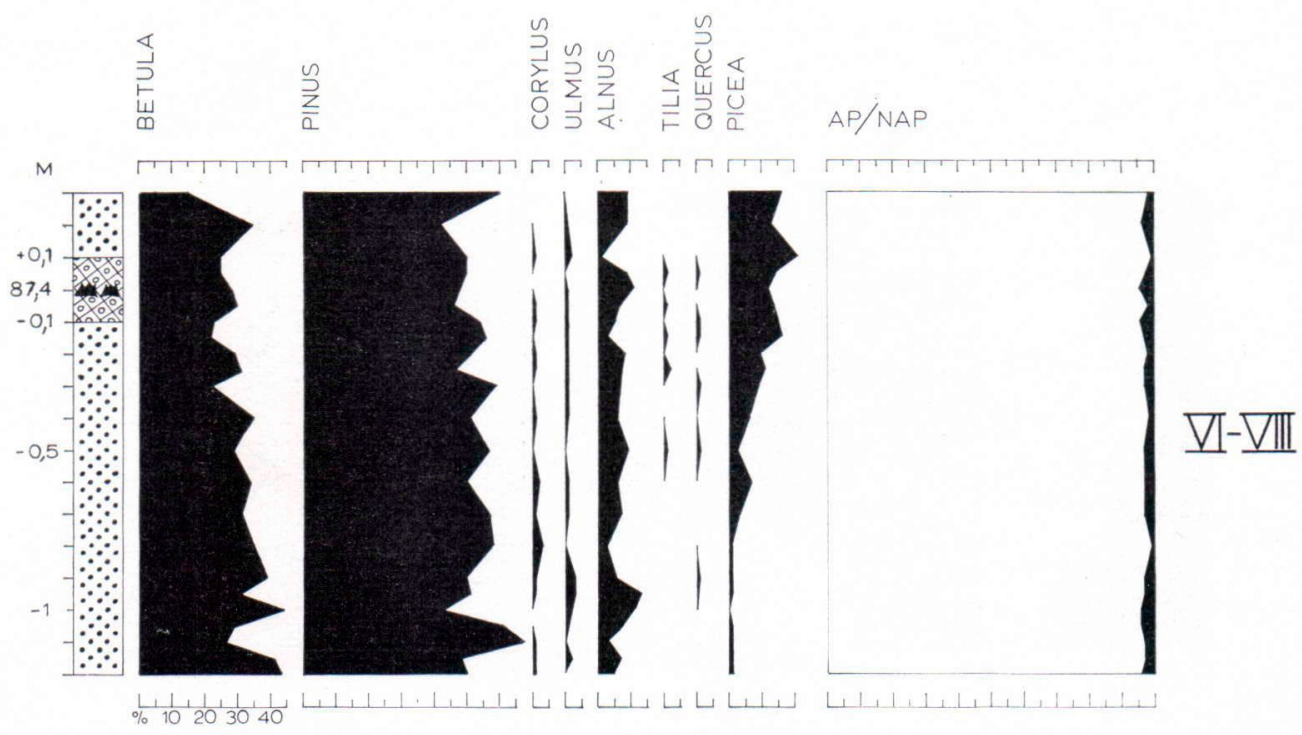

Fig. 14. Pollen diagram 9.

Lahdepohja bog (Sauramo 1958, p. 392, Fig. 134), (diagram 8., Fig. 13). About two kilometres to the northwest of Kunnaslahti bog there is another bog in which even the stratigraphy indicates the transgression. Since the end of zone $\mathrm{V}$ the sedimentation of Equisetumand Phragmites- peat had occured on terrestric peat. The water level in Lahdenpohja at that time was at least at a height of 92 metres. A distinct maximal occurrence of Gramineae in the non-tree pollen is shown in the diagram and the maximal occurrence coincides with the transgression. Lahdenpohja bog began to become embogged during zone IV while the water level was under 91.5 metres.

Vierevänniem1 (diagram 9., Fig. 14). In the draining of Lake Höytiäinen an extensive terrace emerged in Vierevänniemi. Abrasion has formed an abrupt cliff in this place (Fig. 15), which is continuosly diminishing rather quickly. A sandy mud layer has emerged at the present water level and slightly above it. The layer contains many tree trunks, stumps and other organic residue. The amount of organic material decreases clearly about 0.5 meters above the present water level and a cliff composed of fine sand but with only a few trunks continues upwards. Below the tree trunk deposit the organic material soon decreases and at a depth of one meter, clean fine sand is to be found.

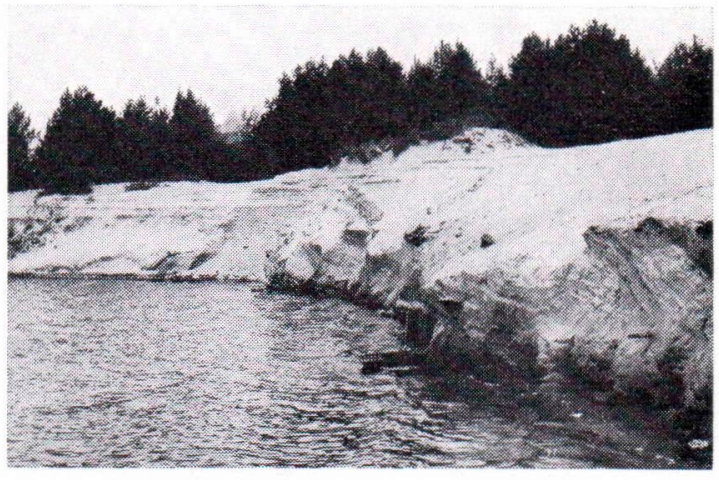

Fig. 15. Vierevänniemi. An abrupt cliff eroded in the sandy terrace of Old Lake Höytiäinen. Near the water level tree trunks and stumps.

This deposit with the trunks indicates the water level at the time during which the trees were still growing quite accurately. After the shore had advanced further on dry land the trunks fell down into the water. As similar development can be seen in Vierevänniemi at the present time. The shore sediment, which is stratigraphically comparable with the tree deposit, is not of the same age. After the trees had become submerged, no sedimentation occured in Vierevänniemi because of the openness of the 
place. This can be seen in the shore profiles which show that the sedimentation of sand before the year 1959 only occured at a depth of $4-5$ metres.

At the time of Picea's immigration the water level was so high that fine sand drifting from the shore covered the trunks. The lowest samples probably formed as early as during zone V. It is hard to determine the hiatus in the stratigraphy. Only C-14 dating could throw light on the determination of the age of the shore and the tree layer.

A diatom analysis was made of the samples (Appendix IV). The flora is heterogenous but indicates the nearness of the shore. Most diatoms are littoral forms or belong to the littoral plankton. The frequent appearance of Cyclotella comta during the Hypsithermal interval shows deep water of southern Lake Höytiäinen (see Mölder 1943). The species differ slightly from the diatom flora of Kiiskisensuo bog. Ecological factors in the wide, open waters in Vierevänniemi differ from those in Kiiskisensuo.

Numerous bog studies of the Lake Höytiäinen region have been published in the work of Sauramo and Auer (1928). Two diagrams of that investigation are presented in the present study, and the zones have been marked in them.

Samples taken from the upper end of Kontiolaht 1 bog (Sauramo and Auer 1928, Appendix IV), (diagram 10, Fig. 16) prove that the water level during zone $\mathrm{V}$ was about 87 meters, because at the same time accumulation peat was deposited at this level. The uppermost Bryales peat is recent. The abundant appearance of Corylus at a depth of 85 centimetres is surprising but the maximal occutrence of Pinus is so clear that dating was possible.

Paskonpohja bog (Sauramo and Auer 1928, Appendix IV), (diagram 11., Fig. 17) is located near the Puntarkoski at the southwestern corner of the lake. The
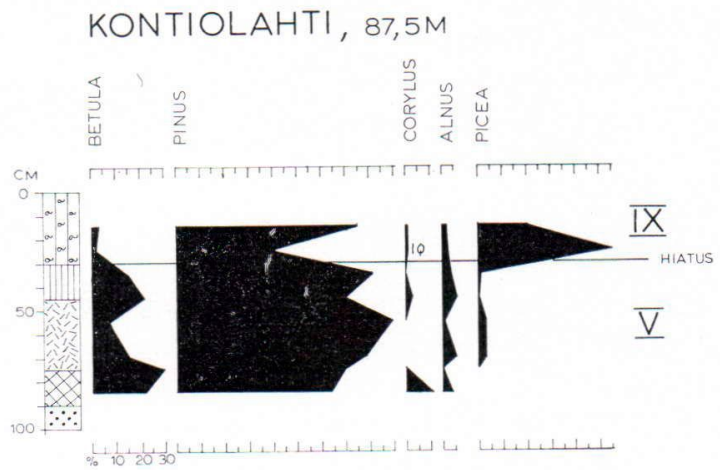

Fig. 16. Pollen diagram 10. (Sauramo and Auer 1928, Appendix IV).

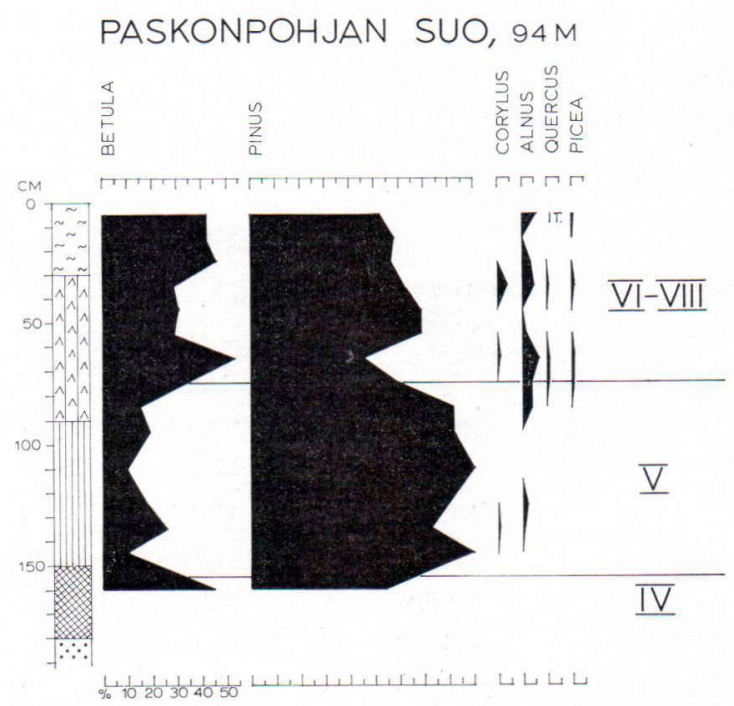

Fig. 17. Pollen diagram 11. (Sauramo and Auer 1928, Appendix IV).

emergence occured at the zone boundary IV/V. Terrestric sedimentation continued for some time after the zone boundary V/VI until the water overflowed the bog which was logated at a height of 94 metres. No telmatic or limnic sediments appear above the Sphagnum-peat.

\section{The Flandrian history of Lake Höytiäinen}

\section{Shore investigations}

The shore of Old Lake Höytiäinen is most distinct at the southern end of the lake where Jaamankangas, composed of abundant loose material, and all the eskers are located. Furthermore, the widest open waters of Lake Höytiäinen are in the southern part of the basin and, additionally, a transgression occured in this area. Therefore erosion has had an increasingly higher reaching effect in this area. At the northern end of the lake, on the other hand, quite opposite factors have prevailed and the development of shore formations has been obscure. On the northwestern side of the $»$ tilt-axis» crossing the Polvijärvi threshold, no open water area exists, shores are rocky, till covers slopes and the water level dropped continuously. Due to these factors the shores are incomplete. 
Formations of the shore of Old Lake Höytiäinen are morphologically dominant in the emerged zone at the southern end of the lake. On shores which have developed in glaciofluvial material one finds that the distal slope of the terrace which is formed of ice driven stones is as distinctive as the cliff. This may cause confusion when determinations of the elevation of raised beaches are made. The shore of 1859 has covered and partly eroded all shore marks below it and thus made the morphological investigation of the earlier stages of the lake impossible. Of the shores eroded in glaciofluvial material often only most recent one can be seen when shores of different ages coincide. This is an obvious obstacle to the investigation of raised beaches. In regression areas, where before the draining the 1859 shore was lowest, it is not even possible to draw synchronous shore lines on the basis of obscure shore marks.

Marine raised be a c hes. Numerous observations concerning raised beaches were made on the same shores as those on which the 1859 shore is most distinct. Marine raised beaches are all older than the zone boundary IV/V. Therefore, it is not possible to check the shore lines, determined by morphological observations, by pollen analysis. The observations on raised beaches are shown in Appendix V.

The Lake Höytiäinen region, which had been eroded earlier deeper than the neighbouring areas, was a Zungenbecken during the last advance of the ice. The ice could not cross the threshold at the southern end of the lake. The height of the threshold was at least 50 metres (the depth of Lake Höytiäinen at the southern end of the basin is 50 metres, and at Puntarkoski bedrock is visible at the present water level). Jaamankangas formed on the threshold at the ice front. The retreat of the ice began from this end moraine in about 8000 B.C. (see Fig. 2), and according to the varve chronology (Sauramo 1928), the ice front was at the northern end of Lake Höytiäinen in about 7850 B.C. Jaamankangas formed during the Yoldia stage of the Baltic Sea. The highest shore line at Lake Höytiäinen corresponds, according to Sauramo's (1937) classification, to the level of Y I. At the end of this stage, ice still existed at the northern end of Lake Höytiäinen and therefore the highest beaches there are even yonger. Water levels (Sauramo's Y II and Y III) cannot be graphically illustrated because only a few observations concerning the waters of the upper Yoldia and the relatively distinct youngest Yoldia (Sauramo's Y IV) are available.

The shore of Sauramo's Y IV is located at the Polvijärvi threshold (at the southern end of Lake Mertajärvi) about 7 metres above the threshold. This point is the only possible isolation threshold because the terrain is so high in other places. The first distinct water level of the last Yoldia stage, the so-called Echeneis Sea, is as much as 20 meters below Y IV (Sauramo 1937). According to this, the youngest marine boundary at Lake Höytiäinen was Y IV. Thus the isolation of the lake took place at the end of the Yoldia regression. There is no evidence that the Ancylus transgression of the Baltic Sea reached Lake Höytiäinen.

Some authors have assumed that there was an ancient connection between Lake Pielinen and Lake Höytiäinen (Sauramo 1928, 1958; Tolvanen 1926). According to these theories, Lake Pielinen had an outlet from Nunnanlahti in Juuka to the northern end of Lake Höytiäinen before the present outlet opened. Hyvärinen (1966, p. 37) agrees with Sauramo's original opinion (1928), according to which the outlet was active already at a much earlier date when the water of the ice-dammed lake was discharged into the northern end of Lake Höytiäinen. However, the isobases of Yoldia IV lie distinctively below the outlet, proving that no connection existed between Lake Höytiäinen and Lake Pielinen.

\section{The Isolation, Lake Höytiäinen as an independent lake}

It is obvious that the shore line of Y IV was about 7 metres above the isolation threshold of 


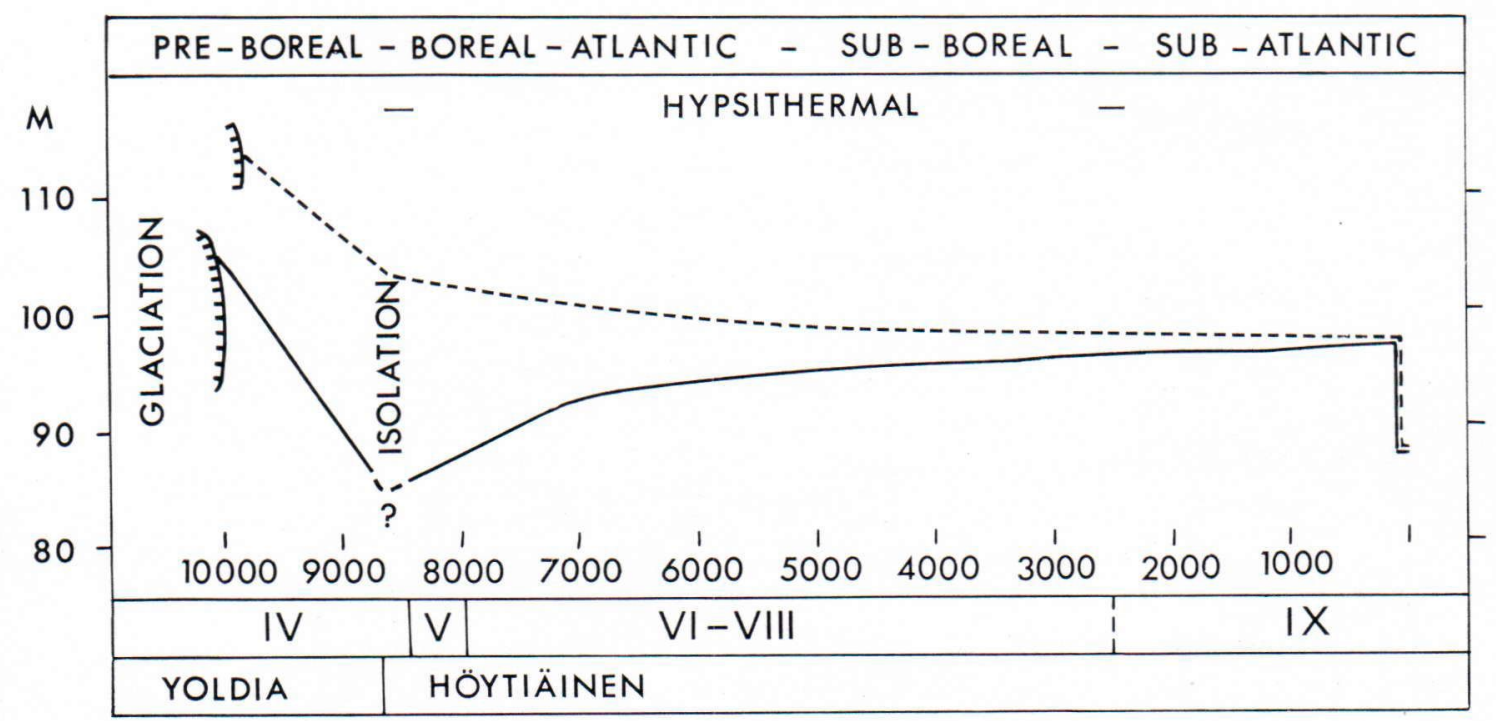

Fig. 18. Schematical representation of the Flandrian shore-line displacement at Jaamankangas (continuous line) and at Martonvaara (broken line) and their relation to Post-glacial periods, pollen stratigraphy and to the Baltic Sea. Years B.P.

Lake Höytiäinen. Kilpi (1937, p. 52) points out that the shore line number VI determined by him is 7 metres above the isolation threshold of Lake Pielinen. This shore line corresponds to Y IV (Kilpi 1937, p. 108, Sauramo 1958, p. 398). The conclusion may be drawn from this that the isolation of Lake Pielinen and Lake Höytiäinen occurred at about same time. Since the land uplift at the threshold of Lake Pielinen has been more rapid than at the threshold of Lake Höytiäinen - the shore of Y IV is over 60 meters higher - the isolation of Lake Pielinen probably occurred somewhat earlier. According to Hyvärinen (1966, p. 37), Lake Pielinen was isolated at about 6900 B.C. and consequently this is the earliest date for the isolation of Lake Höytiäinen.

Sedimentation of terrestric peat at the bottoms of the bogs investigated at the southern end of Lake Höytiäinen occured during zone IV at such a low level that Lake Höytiäinen must have been a lake at that time because the water level was so low. The zone boundary IV/V in the Höytiäinen region dates from the year 6500 B.C., which proves that the lake was isolated before this.
Thus the isolation can be bracketed between the years $6500-6900$ B.C. It probably occured closer to the year 6900 B.C. because already during zone IV, 20 centimetres of peat had been formed. According to Sauramo (1937, 1958), Y IV ended in 7400 B.C.

The changes in diatom flora do not indicate the isolation because the water of the Yoldia Sea in northern Karelia was fresh. The diatom succession of Kiiskisensuo bog indicates regression which is shown by the stratigraphy.

The isolation shore cannot be morphologically determined. The lowest terrestric sedimentation at the southern end of the basin was determined by investigating the shore bogs. By stratigraphy it was also possible to investigate the water levels after the isolation. The results are presented in the same equidistant diagram as the morphological shore observations (Appendix VI). The results concerning Jaamankangas and Martonvaara are shown in Fig. 18. The broken lines (Appendix VI) showing the water levels determined by stratigraphic investigation are tentative. A shore line based both on shore morpho- 
logical and litostratigraphical observations cannot be found at Lake Höytiäinen and therefore a comparison between the different methods is impossible.

In the bogs of Lahdenpohja (diagram 8) and Kunnaslahti (7) terrestric peat had formed already at the end of zone IV. If in the equidistant diagram a line is drawn which passes through the isolation threshold and the lowest boundary of terrestric peat, the highest possible altitude of the isolation shore on the southwestern side of the tilt-axis and its lowest possible location on the northwestern side of the tilt-axis may be determined, assuming that the shore line is linear. At Vierevänniemi, this shore line is situated slightly below a stump deposit located at the present water level. An more accurate determination of the isolation shore by stratigraphy is impossible. The gradient of the determined shore is $49 \mathrm{~cm} / \mathrm{km}$. The gradient of the isolation shore of Lake Höytiäinen determined by Sauramo and Auer (1928) is $39 \mathrm{~cm} / \mathrm{km}$ and the dating of the isolation, based on this information, is between 6800 and 6900 B.C. In other words, the age corresponds to the conclusion of the present study.

After the isolation, a transgression began on the southeastern side of the threshold and a regression on the northwestern side. During zone $\mathrm{V}$ water overflown the forests of Vierevänniemi (9) and the surf had eroded earlier deposits. The Lahdenpohja bog (8) was submerged at the end of zone IV and the formation of Equisetumand Phragmites- peat began. The terrestric peat development continued during zone $\mathrm{V}$ in the Kunnaslahti bog (7), which at that time was on a higher level.

The beginning of zone VI seems to have accelerated the transgression. Already at the beginning of this zone, the bogs in Paskonpohja (11) and Huhmarinen (6) were submerged, assuming that later sediments have not been eroded. The acceleration of the transgression was probably caused by the humid climate during the Atlantic period which increased the amount of water in the basins. The narrow, shallow and bending outlet of Lake Höytiäinen could not discharge the surplus water. In regression areas this slowed down the receding of the shore line. The broken line describing the shore line at the beginning of zone VI is half a meter above the Polvijärvi threshold and indicates the increased amount of water. In Konnunsuo (4) on the tiltaxis, beach-sand formed above the isolation threshold.

In the middle of the Hypsithermal interval, the regression strengthened and the transgression slackened. Viklinsuo bog (3) emerged. In Kiiskisensuo bog (1) clay-mud formed after the zone boundary V/VI. Only a short time before Picea's immigration a transition occurred and the sediments in Kiiskisensuo became terrestric.

Since the immigration of Picea (5000 B.P.) the water level rose at the southern end of the lake about 2.5 metres until the year 1859, and went down at the northern end about 2 metres. If this measurement is accurate, it might be supposed that the tilting of the land $-1 \mathrm{~mm}$ per annum - has been almost the same for 5000 years. The tilt-axis is situated almost in the middle of the SE - NW oriented longitudinal axis of the lake and thus the regression in the north has been $0.5 \mathrm{~mm}$ per annum and the transgression in the south 0.5 per annum, or a total of 2.5 metres in 5000 years.

The rhythm of the water level fluctuation has not been observed since the immigration of Picea. The changes of water level, in any case, have been so small that it would be unsafe to draw any conclusions on the basis of pollen chronology, especially since no distinct transitions in pollen stratigraphy have occurred at Lake Höytiäinen since the immigration of Picea.

In the year 1859 the water level in the lake had reached the 97 meter level. Frequent floods at the southern end were one reason for the draining. In August 1859 the dams of a canal being built in Jaamankangas broke and water eroded an outlet 10 kilometres in length and 0.5 kilometres in width into Lake Pyhäselkä. 
Within one month the water level sank by about 9.5 metres. The old outlet, the Viinijoki stream, dried up. Nowadays, Puntarkoski Rapid in the new outlet has been dammed so that the changes of water level in Lake Höytiäinen are no longer determined by geological development.

Mr. Arto Laitinen translated the text into English for which $\mathrm{i}$ want to express my sincere thanks.

\section{REFERENCES}

AARIo,L. (1936). Entwicklung des südlichen Vor-Päijännesees. - Fennia 62.1.

- (1940). Waldgrenzen und subrezenten Pollenspektren in Petsamo Lappland. - Ann. Acad. Sci. Fennicae 54.8.

- (1952). Über den südlichen Abfluss des Vor-Päijännesees. - Turun yliopiston maantieteen laitoksen julkaisuja. Publicationes instituti geographici universitatis Turkuensis 24 .

Aario, R. (1965). Development of ancient Lake Päijänne and the history of the surrounding forests. - Ann. Acad. Sci Fennicae A, 81.

AlHonen, P. (1967). Palaeolimnological investigations of three inland lakes in south-western Finland. - Acta Botanica Fennica 76.

Autr, V. (1924). Die postglaziale Geschichte des Vanajavesisees. - Comm. Inst. Quaest. Forest. Finl. 8.3.

- (1928). Úber die Einwanderung der Fichte in Finnland. - Comm. Inst. Quaest. Forest. Finl. 13.3.

Berghell, H. (1898). Om Finlands största insjöbäcken, Saimavattnets avlopp förr och nu. - Förh. v.d. 15:de skand. naturforskaremötet.

- (1904). Suomen geologinen yleiskartta, Savonlinna, Lehti D 2. Maalajikartan selitys. - Helsinki.

Cleve-Euler, Astrid, (1946). Om den sista landisens bortsmältning från Södra Sverige, den s.k. Baltiska issjön, tappningarna vid Billingen och Degerfors samt Vätterns historia. - Stockholm.

Deevey, E. S. and Flint, R. F. (1957). Postglacial Hypsithermal interval. - Science 125.

Donner, J. J. (1951). Pollen-analytical studies of Lateglacial deposits in Finland.-Bull. Comm. géol. Finlande 154.

- (1957). The Post-glacial shore-line displacement in the Kuopio district. Ann. Acad. Sci. Fennicae A, III, 49.

- (1963). The zoning of the Post-glacial pollen diagrams in Finland and the main changes in the forest composition. - Acta Botanica Fennica 65.

- (1964). The Late-glacial and Post-glacial emergence of southwestern Finland. - Soc. Sci. Fennica, Commentationes Phys. - Math., 30 (5).

- (1965). The Quaternary of Finland (in Rankama, The Quaternary, Volume 1). - John Wiley \& Sons Ltd., London.
Donner, J. J. (1966). The Late-glacial and early Postglacial pollen stratigraphy of southern and eastern Finland.-Soc. Sci.Fennica, Commentationes Biol., 29 (9).

FAEGRI, K. and Iversen, Johs. (1964). Textbook of pollen analysis. - Munksgaard, Copenhagen.

Florin, MAJ-Brit', (1946). Clypeusfloran i postglasiala fornsjölagerföljder i östra Mellansverige. - Geol. Fören. Förhandl. Bd. 68, H. 3.

Foged, N. (1964). Freshwater Diatoms from Spitsbergen. - Tromsö museums skrifter Vol. XI.

Fromm, E. (1963). Absolute chronology of the late Quaternary Baltic. A review of Swedish investigations (Summaries in German and Russian). - Baltica 1.

Frosterus, B. and Wilkman, W. W. (1917). Suomen geologinen yleiskartta, Joensuu, Lehti D 3. Maalajikartan selitys. - Helsinki.

Hackman, V. (1895). Marina gränser i östra Finland. - Fennia 12.5.

- (1896). Nya iakttagelser angående Yoldia-hafvets utbredning i Finland. - Fennia 14.1.

Heinonen, L. (1957). Studies on the microfossils in the tills of the North European glaciation. - Ann. Acad. Sci. Fennicae A, 52.

HelaAkoski, A. R. (1915). Jouhtenisen saaren rantamuodoista Höytiäisellä. - Terra.

Hellaakoski, A. (1922). Suursaimaa (Deutsches Referat). - Fennia 43.4.

- (1928). Puulan järviryhmän kehityshistoria (Deutsches Referat). - Fennia 51.2.

- (1936). Das Alter des Vuoksi. - Bull. Comm. géol. Finlande 115.

Hustedt, F. (1930). Bacillariophyta (Diatomaceae). - A. Pascher: Die Süsswasserflora Mitteleuropas, 10. Jena.

- (1930-1964). Die Kieselalgen Deutschlands, Österreichs und der Schweiz, mit Berücksichtigung der übrigen Länder Europas sowie der angrenzenden Meeresgebiete. - L. Rabenhorst: Kryptogamenflora von Deutschland, Österreich und der Schweiz, 7.

HrvärINEN, H. (1966). Studies on the late-Quaternary history of Pielis-Karelia, eastern Finland. - Soc. Sci. Fennica, Commentationes Biol., 29 (4).

- (1966 b). A shore-line diagram for the easternmost section of the Salpausselkäs. - Soc. Sci. Fennica; Commentationes Phys. - Math., 33 (4). 
KILPI, S. (1937). Das Sotkamo-Gebiet in spätglazialer Zeit. - Bull. Comm. géol. Finlande 117.

KÄÄRIÄINEN, E. (1953). On the recent uplift of the earth's crust in Finland. - Fennia 77.2.

- (1963). Land uplift in Finland computed by the aid of precise levellings. - Fennia 89.1.

LAPpalainen, V. (1962). The shore-line displacement on southern Lake Saimaa. - Acta Botanica Fennica 64.

Lerviskä, I. (1913). Über den See Oulujärvi und seine Uferformen. - Ann. Acad. Sci. Fennicae, A, III, 12.

Mölder, K. (1943). Studien über die Ökologie und Geologie der Bodendiatomeen in der Pojo-Bucht. - Bull. Comm. géol. Finlande 127.

Oкко, V. (1948). On the Development of the Heposuo bog, near the town of Kuopio. - Bull. Comm. géol. Finlande 142.

- (1965). Kallaveden suurtulvasta. - Savotar V.

PALmén, E. G. (1903). Åldre och nyare sjöfällningar och sjöfällningsförsök i Finland. - Fennia 20.7.

v. Post, L. (1909). Stratigrafische Studien über einige Torfmoore in Närke. - Geol. Fören. Förhandl. Bd. 31. H. 7.

RAmsay, W. (1924). On the relations between crustal movements and variations of sealevel during the Quaternary time especially in Fennoskandia. - Bull. Comm. géol. Finlande 66.

- (1926). Nivåförändringar och stenåldersbosättning i det baltiska området. - Fennia 47.4.

- (1931). Material zur Kenntnis der Spätglazialen Niveauverschiebungen in Finnland. - Fennia 54.3.

REPo, R. (1957). Untersuchungen über die Bewegungen des Inlandeises in Nordkarelien. - Bull. Comm. géol. Finlande 179.

SAARNisto, M. (1965). Ruotsalaisen ja Ala-Räävelin rantojen geomorfologiaa. - Unpublished M.Sc.-thesis.

Sauramo, M. (1928). Über die spätglazialen Niveauverschiebungen in Nordkarelien, Finnland.-Bull. Comm. géol. Finlande 80.

- (1937). Das System der spätglazialen Strandlinien im südlichen Finnland. - Soc. Sci. Fennica, Commentationes Phys. - Math. 9 (10).

- (1939). The mode of the land upheavel in Fennoskandia in late-Quaternary time. - Geol. Fören. Förhandl. 69.
SAURAmo, M. (1940). Suomen luonnon kehitys jääkaudesta nykyaikaan. - Porvoo.

- (1949). Das dritte Scharnier der fennoskandischen Landhebung. - Soc. Sci. Fennica. Vuosik. 27, B, 4.

- (1958). Die Geschichte der Ostsee. - Ann. Acad. Sci. Fennicae A, 51.

Sauramo, M. and Auer, V. (1928). On the development of Lake Höytiäinen in Karelia and its ancient flora. - Comm. Inst. Quaest. Forest. Finl. 13.

Sederholm, J. (1899). Suomen Kartasto - Atlas över Finland.

Srmola, Lrisa, (1963). Ủber die postglazialen Verhältnisse von Vanajavesi, Leteensuo und Lehijàrvi sowie die Entwicklung ihrer Flora. - Ann. Acad. Sci. Fennicae $A, 70$.

SIrÉN, A. (1951). On computing the land uplift from the water level records in Finland. - Fennia 73.5.

Tolonen, K. (1967). Über die Entwicklung der Moore in finnischen Nordkarelien. - Ann. Bot. Fennici 4.

Tolvanen, V. (1922). Der Alt-Päijänne. - Fennia 43. - (1924). Muinais-Näsijärvi. - Terra.

- (1926). Itä-Suomen vesistön kehityshistoriasta. - Suomen Matkailijayhdistyksen vuosikirja.

TrnnI, R. (1966). Über spät- und postglaziale Uferverschiebung in der Gegend von Askola, Südfinnland. - Bull. Comm. géol. Finlande 223.

VarJo, U. (1964). Über finnische Küsten und ihre Entstehung. - Fennia 91.2.

West, R. G. (1963). Problems of the British Quaternaty. - Proc. Geol. Assoc. London 74 pt. 2.

WILKMAN, W. W. (1912). Kvartära nivåförändringar i östra Finland. - Bull. Comm. géol. Finlande 33.

VIRKKALA, K. (1948). Suomen geologinen yleiskartta, Nurmes, Lehti D 4. Maalajikartan selitys. - Helsinki.

- (1962). Suomen geologinen kartta, Tampere, Lehti 2123. Maaperäkartan selitys (Explanation to the map of superficial deposits, sheet 2123, Tampere, with an English summary). - Helsinki.

- (1966). Radiocarbon ages of the Råbacka bog, southern Finland. - Bull. Comm. géol. Finlande 222.

Manuscript received, February 6, 1968. 
Explanations for Appendices

Appendices I-II. Shore profiles.

Appendix III. Diatom diagram of the Kiiskisensuo bog.

Appendix IV • Diatom diagram of Vierevänniemi.

Appendix V. Map of Lake Höytiäinen with the names of the places used in this study showing the sites of shore observations and sites for pollendiagrams. Site $\mathbf{5}$ for raised beach is missing, but should be immediately east of $\underline{4}$.

Appendix VI. Shore-line diagram of the basin of Lake Höytiäinen. The direction of the baseline and the explanation for the observations on the raised beaches are given in Appendix V. The broken lines showing the water levels, determined by stratigraphic investigations, are tentative.

Appendix I

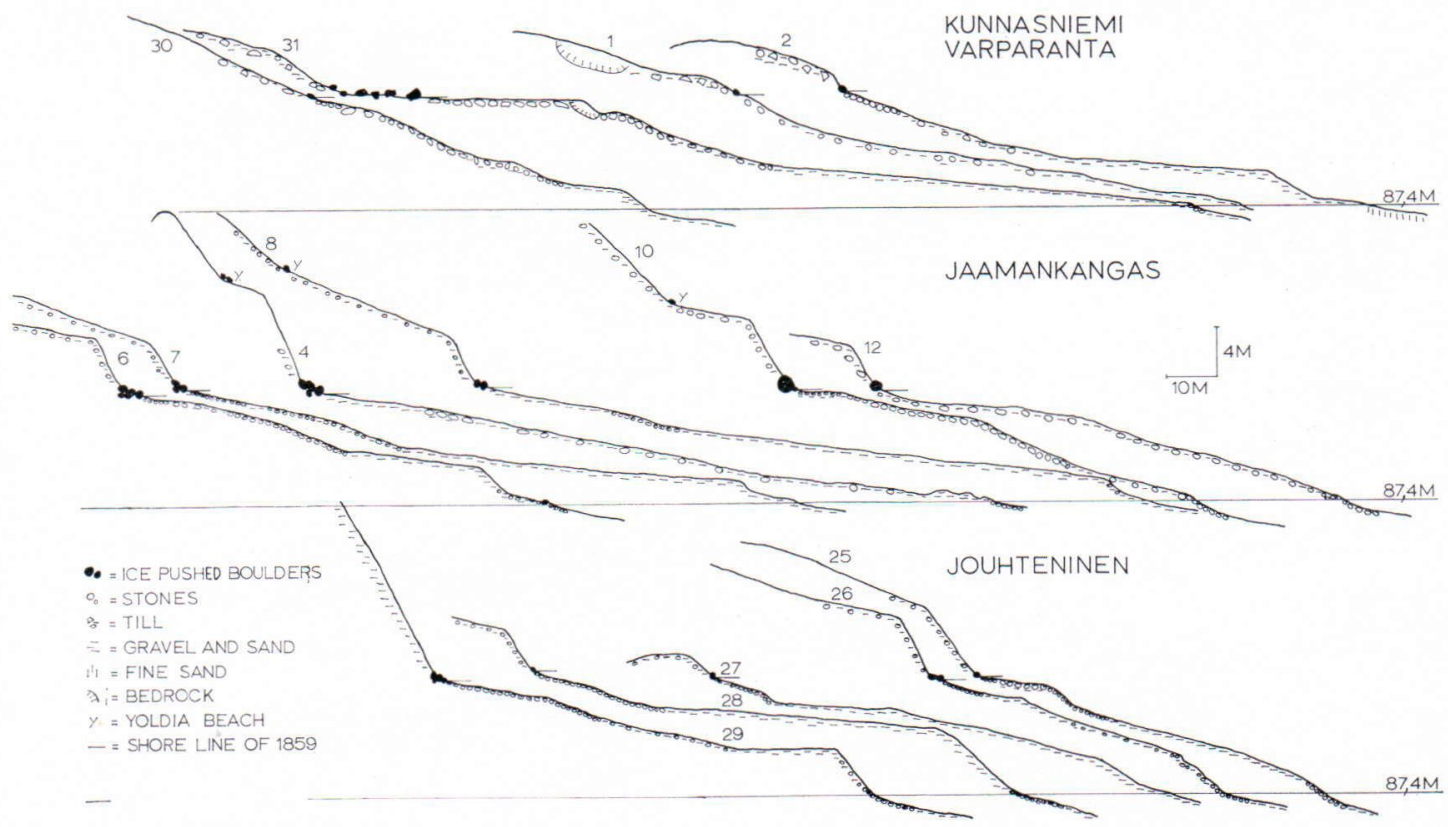




\section{Appendix II}

$87,4 \mathrm{M}$
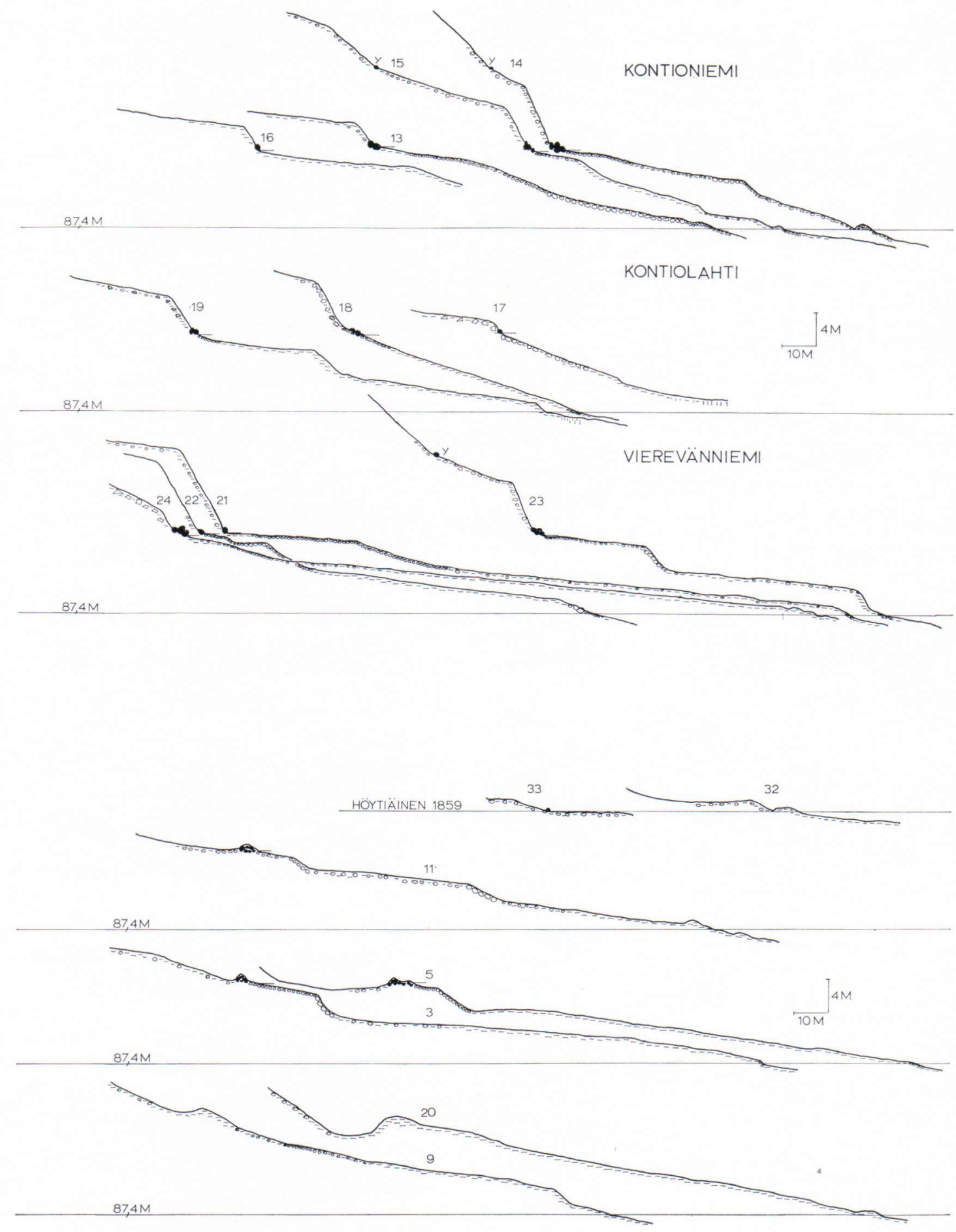


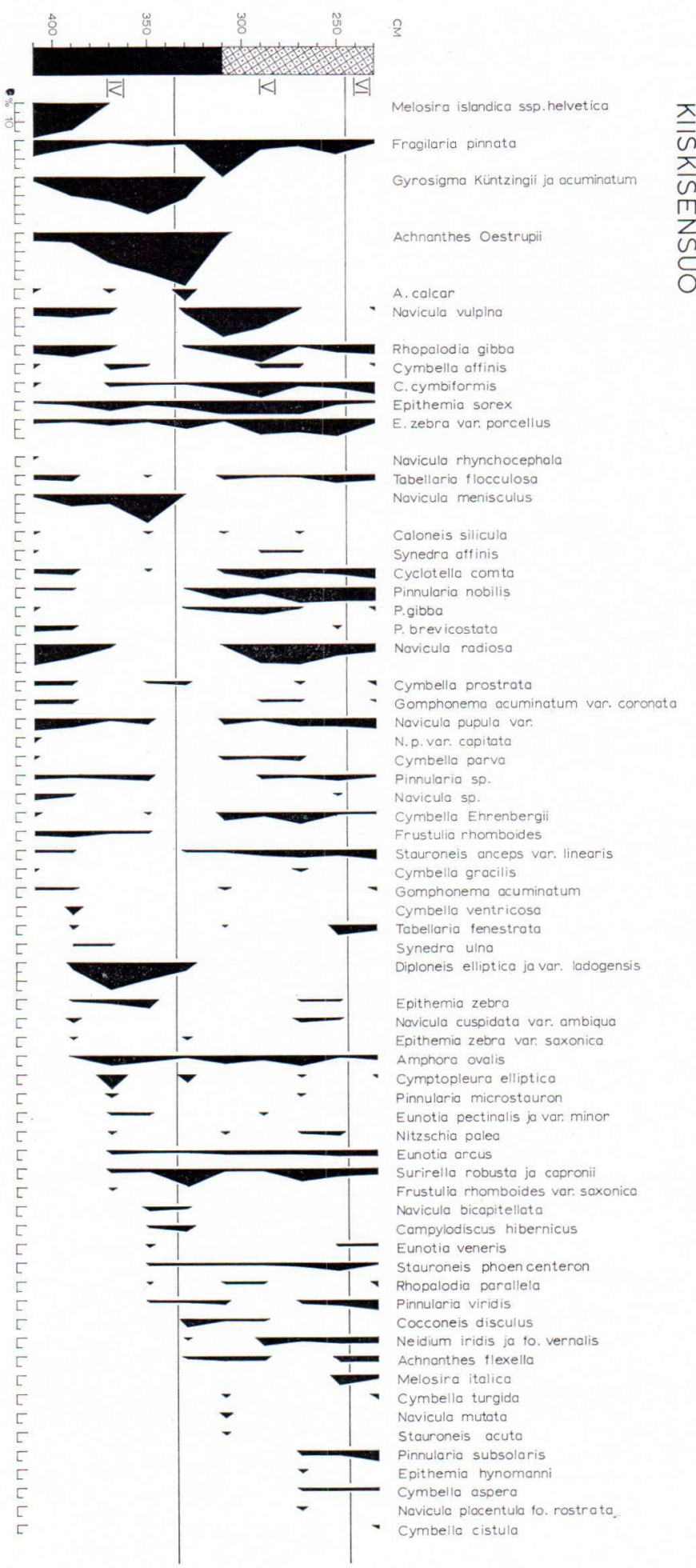




\section{Appendix IV}

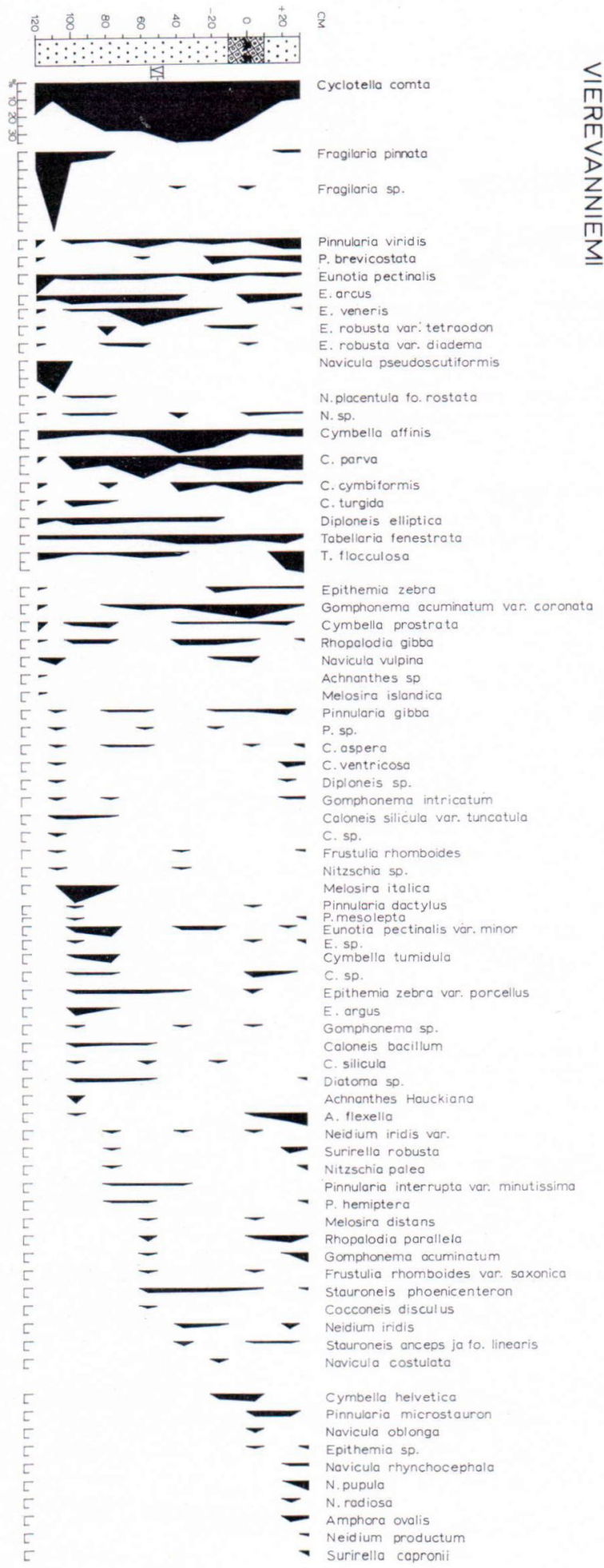


Appendix V

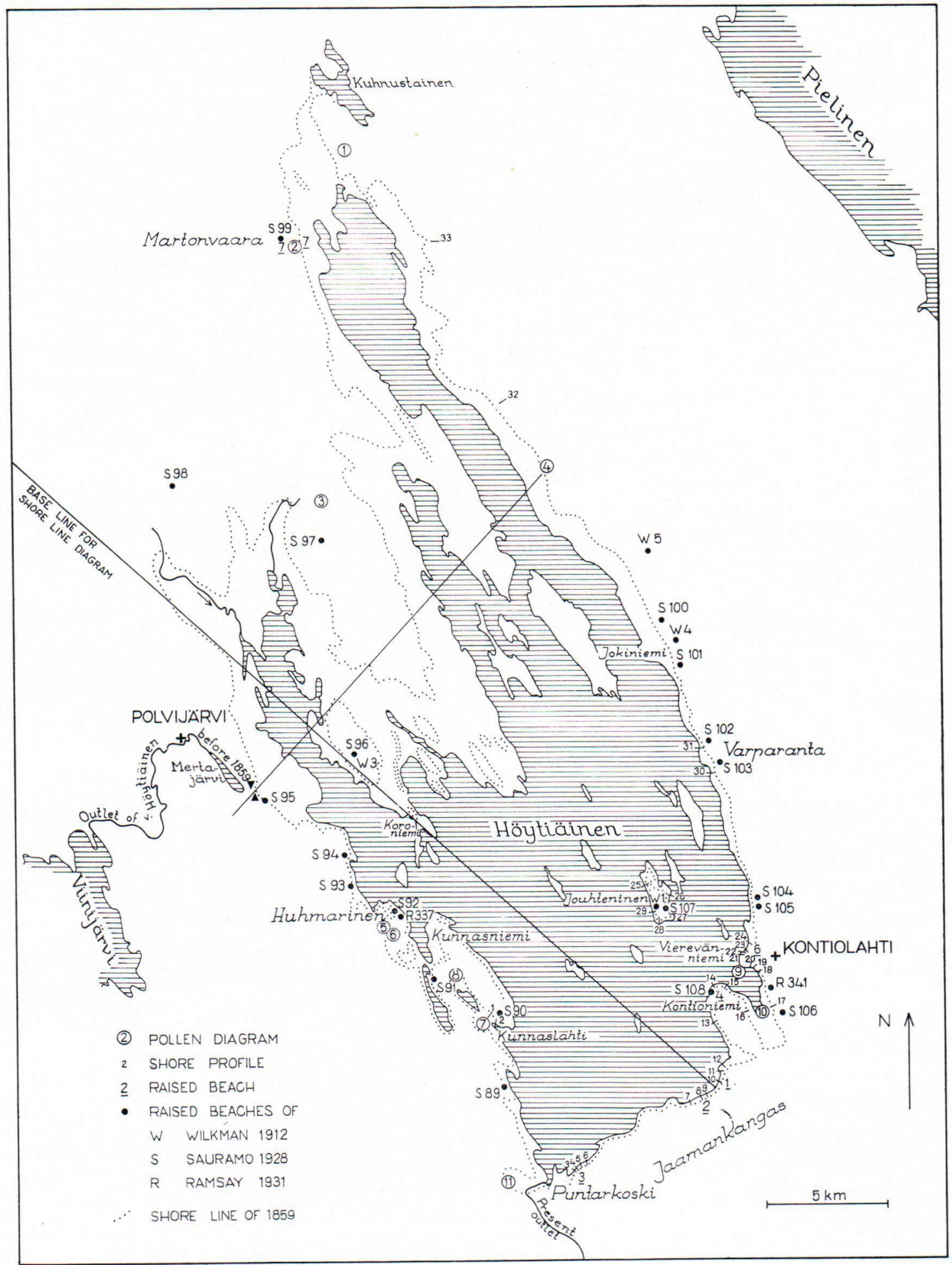




\section{Appendix VI}

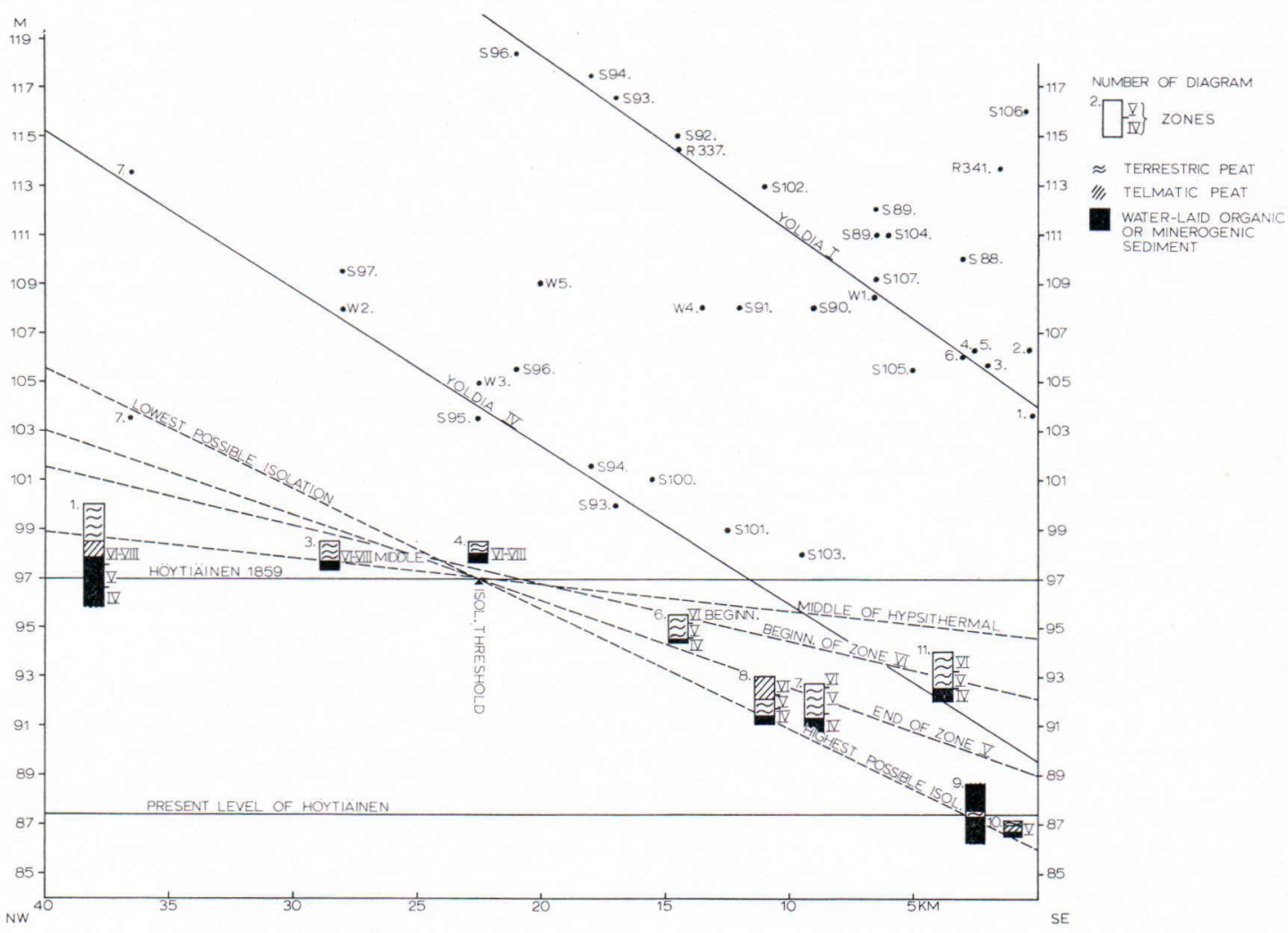

